\title{
RECENT DeVelopments in SURFACE Rights LAW - PIPELINE Right-OF-Way COMPENSATION - ANNUAL PAYMENTS AND INJURIOUS AFFECTION - Federal AND ALBERTA DEVELOPMENTS
}

\author{
LARS OLTHAFER
}

Landowners have recemly advanced novel claims for right-of-way compensation in connection with both federally and provincially regulated pipelines. The compensation paid for the acquisition of pipeline righis-of-way in Canada has typically been, with some notable exceptions, in the form of one-time payments for the value of the interest in land acquired. and any injurious affection to the remaining lands of the owner. However. relying on the precedents established by a feu pipeline companies and the provisions for annual or periodic compensation under the Alberfa Surface Rights Act and the National Energy Board Act. landowners have affempled to secure compensation anvards in the form of rental payments, the present value of which is several times greater than the compensation historically payable as a lump sum.

This article examines two recent court decisions the Alberta Court of Queen's Bench decision in Zubick v. Corridor Pipeline Limited and the Federal Court of Appeal's ruling in Balisky $v$. Canada (Minister of Natural Resources) - as well as a group of National Energy Board Act Pipeline Arbitration Committee anvards in Alberta. and discusses their impact on pipeline rights-of-way compensation.
Les propribfaires fonciers viennent de faire de nouvelles demandes dindemnisation d'emprises relativiment aux pipelines régis par les gouvernements fideral el provinciaux. L'indenmisation versée au Canada pour l'acquisition d'emprises, hormis quelques exceptions notoires, se fait sous la forme de paiements uniques correspondant à la valeur de la terre acquise et de tout effet prijudiciable au resfe de la terre du propriefaire. Cependant, se fiem anx précédents élablis par quelques compagnies de pipelines et aux dispositions des indemmités ammuelles el periodiques en veriu de la Surface Rights Act de I'Alberla el de la Loi sur l'Office national de l'énergie, des propriétaires ont essajé d'obtenir des indemmiés sous forme de loyers, dom la valeur acticlle représente plusieu's fois l'indemnifé versée traditionnellemem sous forme de somme forfaitaire.

Cet arficle examine deux récentes décisions. notamment celle de la Cour du banc de la Reine de I'Albersa dans Zubick v. Corridor Pipeline Limited el celle de la Cour d'appel fédérale dans Balisky c. Canada (Ministre des Ressources naturelles) ainsi que les dommages iniérèts accordés en Alberta par im conilé d'arbilrage en veriu de la Loi sur l'Office national de l'énergie, é étudie leurs incidences sur rindemisation d'emprises.

\section{TABLE OF CONTENTS}

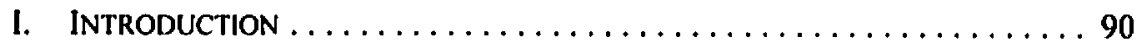

A. ANNIALL COMPENSATION $\ldots \ldots \ldots \ldots \ldots \ldots \ldots \ldots \ldots, \ldots$

B. INIURIOUS AFFECTION $\ldots \ldots \ldots \ldots \ldots \ldots \ldots \ldots \ldots \ldots$.

11. DEVELOPMENT OF SURFACE RIGITTS

Compensation Regimes . . . . . . . . . . . . . . . . . . 92

A. FEDERAL: NATIONAL ENERGY BOARD ACT .............. 93

B. ALBERTA: SURFACE RJGHTS ACT ................ 94

III. SURFACE RIGHTS COMPENSATION JURISPRUDENCE

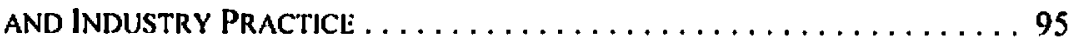

A. EXPROPRIATION COMPIENSATION PRINCIPLES ............ 96

B. FEDERAl: SURFACE RIGIITS COMPENSATION

JURISPRUDENCE AND INDUSTRY PRACTICE $\ldots \ldots \ldots \ldots \ldots \ldots 99$

P.Eng., LL.B., Partner, Fraser Milner Casgrain LL.P. The author acknowledges the considerable assistance of Laura Estep and Birch Miller in the preparation of this article. 


\section{Alberta: SURFACE RightS COMPENSATION}

JURISPRUdENCE AND INDUSTRY PRACTICE . . . . . . . . . 100

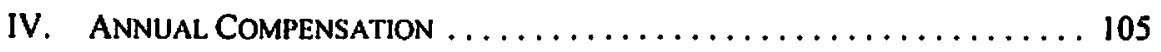

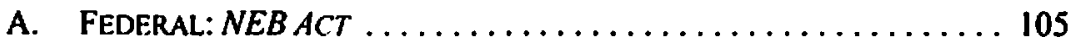

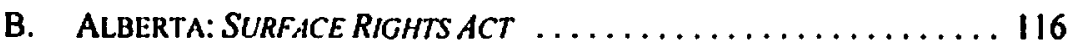

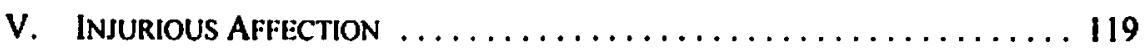

A. FEDERAl: NEB ACT SECTION 112

"Controllled AREA" ..................... 120

B. AlbERTA: DE FACTO PIPELINE CORRIDOR $\ldots \ldots \ldots \ldots \ldots \ldots \ldots$

VI. SURFACE RIGHTS COMPENSATION

Practice Considerations . . . . . . . . . . . . . . . . 126

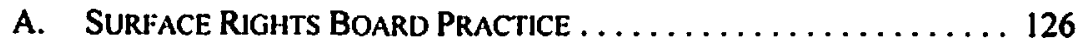

B. Pipeline Arbitration Committee Practice $\ldots \ldots \ldots \ldots \ldots \ldots 127$

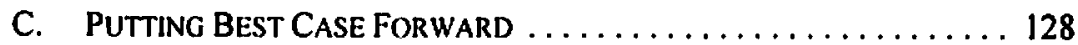

VIl. CONCLUSION $\ldots \ldots \ldots \ldots \ldots \ldots \ldots \ldots \ldots \ldots \ldots \ldots \ldots \ldots \ldots \ldots$

\section{INTRODUCTION}

Landowners in Alberta have recently advanced novel claims for annual compensation and injurious affection for pipeline right-of-way' acquisition, in connection with both federally and provincially regulated undertakings. Though these claims have generally not translated into substantially increased awards, they demonstrate the problems inherent in the prevailing disregard for sound expropriation law principles in the context of surface rights compensation.

\section{A. Annual Compensation}

The issue of annual compensation for pipeline rights-of-way has arisen recently in the context of both provincially and federally regulated pipelines in Alberta.

The Alberta Court of Queen's Bench, hearing an appeal from the Surface Rights Board (SRB), addressed annual compensation for pipeline rights-of-way under the Alberta Surface Rights Act in its May 2002 decision in Zubick v. Corridor Pipeline Ltd. ${ }^{3}$ In July 2002, the SRB had occasion to revisit the issue, again in relation to claims for compensation arising from the taking of rights-of-way by Corridor Pipeline Limited.

The issue of annual compensation for pipeline rights-of-way is not, however, being pursued exclusively through the SRB and the courts in Alberta. Pipeline arbitration committees appointed by the federal Minister of Natural Resources under the National Energy Board $A c r$ have also been seized of the issue of late.

The term "right-ol-way" here is used in the context of utility rights-of-way in respect of which the benefit of the right is not appurtenant or annexed to any land of the grantec. See. for example. Alberta Land Tilles Act. R.S.A. 2000. c. L.4, s. 69, which allows for the registration of pipeline rights-of-way. R.S.A. 2000, c. S-24 [Surface Rights Act]. (2002), 315 A.R. 274 (Q.B.) [Zubick].

R.S.C. 1985, c. N.7 [NEB Acr]. 
The statutes governing the determination of appropriate compensation to be paid for the acquisition of lands for the purposes of provincially or federally regulated pipelines are different in several important respects. Annual payments, while explicitly contemplated under the Surface Rights Act for ongoing loss of use and adverse effect, have traditionally not been awarded by the SRB or the courts in Alberta in relation to pipeline rights-of-way. Under the $N E B A c t$, however, it is left to the landowner to elect the method of compensation payment.

These apparently contrasting approaches to pipeline right-of-way compensation are likely to become only more evident and practically more difficult to reconcile with the increasingly common incidence of federally and provincially regulated pipelines traversing the same property. However, adherence to the expropriation compensation principle of economic reinstatement and sound economic theory should effectively produce similar, if not identical, results. ${ }^{5}$ Unfortunately, surface rights compensation awards, particularly in Alberta, have often been overly sensitive to perceptions of what constitutes equitable compensation results as between landowners.

\section{B. INJURIOUS AFFECTION}

Claims of compensation for injurious affection in relation to pipelines are not new; however, the manner in which several such claims have recently been framed in relation to federally regulated pipelines across Canada, and provincially regulated pipelines in Alberta, is. ${ }^{\circ}$

In the context of federally regulated pipelines, owners have claimed compensation for the perceived restrictions on the use of their lands within the so-called "controlled area" established on either side of a pipeline right-of-way by s. 112 of the NEB Act. This is done on the basis that it either constitutes a de facto acquisition of, or injuriously affects, their remaining lands. Compensation for the "controlled area" has been pursued through the NEB $A c t$ arbitration procedures by owners of lands traversed by federally regulated pipelines in Alberta, British Columbia, Nova Scotia and Ontario. ${ }^{7}$ The consideration of the "controlled

3 Kenneth J. Boyd, Expropriation in Canada (Aurora, Ont.: Canada Law Book Inc., 1988) at 30-33. Reinstatement would theoretically be assured in the casc of pantial takings by the application of the "before and after" method. That method entails the determination of the market values of the entire parcel immediately before the taking and the remaining parcel after the partial taking, and the difference, if any, is deemed to be the appropriate measure of compensation for the taking and any injurious affection to the remainder. However, the application of the method is arguably precluded by statutes that require the separate determination of the market value of the lands taken and injurious affection to the remaining lands, plus other specifically enumerated heads of compensation. Injurious affection in this context is meant as severance damage or reduction in market value (as distinct from other commonly recognized incidental or consequential damages or adverse effects, such as interference with normal farming patterns during pipeline construction).

Nova Scotia: Maritimes \& Northeast Pipeline Lid. v. Elliott (2004), 238 D.L.R. (4th) 358 (F.C.T.D.) [Maritimes \& Northeas'], involving an application for judicial review of the decision of the Minister of Natural Resources to refer to arbitration under Part V of the NEB ACt a claim for compensation for injurious affection though none of the owners' lands were taken for the company's pipeline. Though some part of the owners' lands were recognized to fall within the NEB ACt s. 112 controlled area associated with the company's pipeline, the judge did not address the matter on the basis that the owners did not specifically contest that part of the Minister's decision barring the consideration of the controlled area for purposes of compensation. The case appears to leave open the issue of compensation claims by owners of adjacent lands affected by the controlled area. 
area" for purposes of compensation was referred to arbitration by the federal Minister of Natural Resources after his initial refusal to do so was reversed upon judicial review by the Federal Court of Appeal in Balisky v. Canada (Minister of Natural Resources). ${ }^{8}$

In Zubick, an Alberta Surface Rights Act case, premium compensation was awarded in recognition of the perceived impacts on owners' long-term use of their lands as a result of a de facto corridor created by parallel multiple linear developments.

A discussion of these recent developments in surface rights compensation for pipeline rights-of-way requires an overview of the development of the federal and Alberta surface rights compensation statutory regimes and jurisprudence.

\section{Development of SuRface Rights Compensation Regimes}

The power to take land from private owners for public purposes is recognized as a necessity of modern government. ${ }^{10}$ Owners' claims for compensation for such takings in Canada, either for the land taken or for the damage to the remaining lands of the owner (injurious affection), must be founded on a statutory right." "In that context, it is notable that separate statutory regimes have frequently been established for the expropriation of property by the Crown or its authorized agencies, and the taking of surface rights by pipeline companies. $^{12}$

Ontario: The Canadian Alliance of Pipeline Landowners Associations and two individual landowners have commenced an action, which they will be applying to have certified as a class action, against Enbridge Pipelines inc. and TransCanada Pipelines Limited claiming damages for alleged restrictions on the use of their lands within the NEB ACt s. 112 controlled area.

(2003), 301 N.R. 104 (F.C.A.), rev'g (2002), 223 F.T.R. 138 (T.D.), leave to appeal refused, [2003] S.C.C.A. No. 193 [Balishy C.A.].

Supra note 3.

"' See Eric C.E. Todd, The l.an' of Expropriasion and Compensation in Canada. $2 \mathrm{~d}$ ed. (Scarborough, Ont.: Carswell, 1992) at 1 . It is accepted that the Iegislature of a province has a general power to expropriate property by virtue of its legislative power over property and civil rights in the province under the Constitution Act, 1867 (U.K.), 30 \& 31 Vict., c. 3, s. 92(13), reprinted in R.S.C. 1985, App. II. No. S. The federal expropriation power, however, appears to he limited to the taking of property for purposes otherwise falling within its legislative authority.

In Canada there is no constilutional guarantee of compensation for expropriated property rights. Accordingly, compensation claims for expropriation must be established on a statutory right (Sisters of Charity of Rockingham v. The King. [1922] 2 A.C. 315 al 322 (P.C.)). However. Canadian courts will apply the principle of statutory interpretation that raises a presumption in favour of payment of full compensation (British Columbia v. Tener, [1985] I S.C.R. S33 at 559: Allorney-General v. De Keyser's Royal Hotel, [1920] A.C. 508 at 542 (HI.L.)). With regard to the determination of compensation in accordance with statutory criteria, sec Bank of Nova Scotia v. Nova Scotia (1977). 22 N.S.R. (2d) 568 at 592 (C.A.).

1: Saniak v. Paloma Petroleum Lsd (1989), 101 A.R. 306 at para. 4 (C.A.) [Sawiak]. The distinclion lias typieally been made in relerence to a mineral rights owner, the tiking of whose minerals would not be considered an expropriation at all but for the establishment by statute of a "surface owner's rights to be compensated for whatever infringement of his surface rights (unencumbered by any mineral owner's rights) is suffered as a result of granting the mineral owner a right of entry:" See Cabre Exploration Led. V. Arndt (1986), 69 A.R. 296 (Q.B.): Borys v. Canadian Pacific Railway, [1953] 2 D.I.R. 65 at 75 (P.C.) 
In relation to both provincially and federally regulated pipelines in Alberta, the early 1980 s can be considered a watershed period with regard to terms of surface rights legislation reform.

\section{A. FEDERAL: NATIONAL ENERGY BOARD ACT ${ }^{13}$}

Until 1983, compensation under the $N E B A C$ was determined in accordance with certain specified provisions of the Railway $A C^{14}$ that were applied mulatis mutandis to federally regulated pipelines. ${ }^{15}$ The Railway $A c t$, which had not been significantly amended since 1919, provided for compensation for the acquisition of lands to be fixed by a superior court judge in the event that a company and an owner did not agree as to the amount of compensation payable. The arbitrator was given virtually no guidance as to how to ascertain the compensation payable, being merely directed to proceed in such a way as he or she deemed best. There was no requirement for the company to pay an advance of compensation to the owner, and the costs of arbitration could be awarded against either party.

The NEB Act was amended in $1983^{10}$ to modernize the statutory procedures used by pipeline companies under federal jurisdiction to acquire lands. ${ }^{17}$ Among other things, the amendments, which are essentially unchanged to this day, ${ }^{18}$ provide for:

- the codification of the types of damage for which compensation should be payable; ${ }^{19}$

- an advance payment on the compensation payable upon the issuance of a right of entry to the company; ${ }^{20}$

the referral by the Minister of Natural Resources of compensation disputes, including in relation to the amount of the advance payment, to an ad hoc arbitration committee whose procedures are set out in regulations: ${ }^{21}$

owners to be given the option to receive the compensation payable to them as a lump sum, or by periodic payments subject to review, having regard to changes in market value of the lands, at five-year intervals; ${ }^{22}$

- the payment by the company of the owners' reasonable costs for arbitration; ${ }^{23}$ and

Under the NEB ACt, supra note 4, the National Eenergy Board has regulalory authority over, anong other things, the certitication that a pipeline is in the public convenience and necessity, detailed routing. expropriation. leave to open. operation and abandonment. However. the processes for determining compensation under the $N E B A C l$ for the acquisition of lands and damages arising from construction and operation of a pipeline is adininistered by the Minister of Natural Resources. R.S.C. 1970 , c. R-2. ss. $160-61$.

National Energy Board ACI. R.S.C. 1970. c. N-6. s. 75.

S.C. $1980-81-82-83$, c. 80. S. 5 . as am. by R.S.C. 1985. c. N-7.

House of Commons Debates, 155 (6 March 1981 ) at 8006 (Hon. Marc Latonde) [House Debares]. See referenced Law Reform Commission of Canada, Report on Expropriation. No. 132-1/9-1975 [LRCC on Expropriation] setting out the major recommendations of the I.RCC on expropriation powers conferred under federal statutes.

Sec $N E B$ Acl, supra note 4 at $165-69$ (table of concordance).

lbid., s. 97.

lbid., s. 105 .

Ibid., ss. 88. 90. 91. 105. 107(d) and see also tlic Pipeline Arbitration Commintee Procedure Rules. 1986. S.O.R./1986-787 [Procedure Rules]

:2 $\quad$ NEB ACt. supra note 4. s. 98.

$3 \quad$ ibid. s. 99 
an appeal to the Federal Court Trial Division from the decision of an arbitration committee on questions of law and jurisdiction. ${ }^{24}$

\section{B. ALBERTA: SURFACE RIGHTS ACT ${ }^{25}$}

Starting in 1947 , shortly after the Leduc discovery, through to 1972, the arbitration of compensation for rights of entry was governed by the Right of Entry Arbitration Act. ${ }^{26} \mathrm{This}$ Act, inter alia, established a compensation scheme for rights of entry granted for mining, drilling and pipeline operations. The Alberta Legislature conducted a review of the Board of Arbitration's compensation decisions ${ }^{27}$ and in 1972, the Right of Entry Arbitration Act was repealed and substituted with the Surface Rights Act. ${ }^{28}$

The Surface Rights $A c t$ substantially amended the compensation scheme in several respects. In respect to the compensation payable, it expanded the list of factors the newly established SRB could consider and created other discretionary grounds for compensation in relation to specified ancillary damages or losses. ${ }^{29}$ It also created a process for the SRB to review and change prior compensation orders and to review orders made payable on "an annual or periodic basis" regularly. ${ }^{30}$ It also expanded the discretion of the SRB to award costs to owners. ${ }^{31}$

Subsequent amendments to the Surface Rights Act provided for additional specific heads of damages and interest on compensation awards. ${ }^{32}$

In 1983, the Surface Rights $A \mathrm{At}^{33}$ was repealed and replaced, ${ }^{34}$ and surface rights compensation was substantially reformed again. The new Surface Rights $A c t$ required the

23 In Alberta, the construction and operation of provincial pipelines are approved by the Alberta Energy and Utilities Board pursuant to the legislation it administers, including the Pipeline Act, R.S.A. 2000, c. P-15. Both rights of entry for pipelines and the determination of associated compensation are left to be determined by the SRB, whose constituting statute is the Surface Rights Act, supra note 2. R.S.A. 1970, c. 322; R.S.A. 1955, c. 290; S.A. 1952, c. 79; S.A. 1947, c. 24. Alberta, Legislative Assembly, Hansard, 46 (9 May 1972) at 16.20 (Mr. Zander).

S.A. 1972, c. 91 (effective I August 1972).

These factors included: the value of the land; loss of use; adverse effect; nuisance, inconvenience and noise; damage to the lands; and such other factors as the SRB considered proper. Aneillary damages or losses recognized werc: damage to land outside of the area granted to the operator; loss of or damage to livestock or other persunal property; and time and expense of recovering livestock that have strayed. Alberta, Legislative Assembly, Hansard, 46 (9 May 1972) at 32 (Mr. Henderson), 35 (Mr. Hinman), 36 (Mr. Benoit). In relation to the new five year review rule created in 5. 36, the Hansard Record suggests that the Legislative Assembly of Alberta intended to address the perceived injustice of inconsistent compensation orders being awarded over time. This inconsistency was attributed to the changes in the value of land over time due to rapidly escalating inflationary costs of land values and changing land uses.

"While costs had long been in the discretion of the Board of Arbitration under the carlier legislation. the SRB was empowered to consider preliminary costs of an owner in deciding whether or not to accept an operator's offer of compensation.

"2 For example, The Surface Rights Amendment Act, S.A. 1976, c. 85, granted the SRBB the power to award compensation for necessary relocation expenses in cases where the owner or occupant was required to relocate his residence as a result of a right of entry order, as well as interest. See Alberta, Legislative Assembly, Hansard, 55(18 October 1976) at 1522 (Mr. McCrae).

34 S.A. 1983, c. S-27.I (effective 4 July 1983). 
payment to the owner of 80 percent of the last offer of compensation, as well as a flat rate per acre entry fee ${ }^{35}$ (which was in addition to any compensation determined to be payable under the $A c t$ ) before an operator could exercise a right of entry. It also expanded on the factors the SRB could consider to establish land value, and expressly permitted the SRB to disregard "the residual and reversionary value" of the land to the owner. ${ }^{36}$

With respect to annual or periodic compensation under the Surface Rights $A c t$, subsequent amendments to the legislation more precisely narrowed the scope of factors to be considered in setting the "rate of compensation" to loss of use and adverse effect."

\section{SURface Rights COMPENSATION JURISPRUdENCE AND INDUSTRY PRACTICE}

Surface rights legislation has sometimes been curiously distinguished from expropriation law "as a statutory scheme expressly founded on compensation rather than valuation." either context, what is involved is the acquisition, pursuant to statutory powers, of a property interest without the consent of the owner. Differences in particular statutory provisions, notwithstanding the reasons for significant differences between compensation for, on the one hand, a statutory right of entry for an oil or gas pipeline and, on the other, an expropriation of a sewer pipeline easement, are not readily apparent, though arguably irrelevant policy considerations may be a significant factor. Accordingly, although expropriation law, per se, does not strictly apply to surface rights of entry, the compensation principles upon which it is founded ought to, provided that they are applied correctly. ${ }^{30}$

Alberta, Legislative Assembly, Mansard, (31 May 1983) at 1252-54, 1256 (Mr. Fjordbotten), indicates that "an increasing concern regarding the level of compensation" being awarded by the SRB was one reason why the Legislature rewrote the legislation in 1983. The financial concern was based on the increase in land values and "the growing appreciation of the correlation betiveen the activities of the energy industry and [the farmers' increased] operating costs and reduced revenues. To address these concerns, a "one-time initial payment" (i.e. . the entry fee) was introduced to provide compensation for the formerly unrecognized loss of the farmer's right of ownership over the land (i.e., for farmers not having a say on who may enter their land).

Supra note 2, s. 25(2). In determining land value, the SRB could consider the amount the land granted to the operator might be expected to realize if sold in the open market by a willing seller to a willing buyer on the date the right of entry order is made, and the per acre value of the titled unit in which the land is located based on the land's highest approved use (ibid., ss. 25(1)(a)-(b)). See Surface Rights Act, ibid, ss. 27(I)(d). 25(1)(c)-(d).

Sawiak, supra note 12 at 64 . See also Murphy Oil v. Dau (1969), 7 D.L.R. (3d) 512 at 519 (Alta. C.A.), aff d [1970] S.C.R. 861; Todd, supra note 10 at 437.38 (referring to United Management Led. v. Calgary (City of (1986), 70 A.R. 23 at para. 29 (L.C.B.)). The claimed distinction appears to arise from the incorrect perception that expropriations deal exclusively with takings of whole parcels of land, whereas surface rights acquisitions are exclusively for partial takings. In fact, expropriations are frequently for partial takings (e.g. highways), including takings of less than a fee simple interest (e.g., sewer line easements). It should also be noted that, whether an expropriation is undertaken by a public body or a private enterprise, the expropriation authority is typically granted in recognition of the public interest served by such undertakings.

3) Todd, ibid. at 436 (referring to Dome Peiroleum v. Juell (1982), I43 D.L.R. (3d) 360 at 363 (B.C.S.C.), which follows Dau v. Murphy Oil, [1970] S.C.R. 861. 
The general principle underlying statutory compensation is that the owner whose property rights are taken is entitled to economic reinstatement. ${ }^{+0} \mathrm{With}$ respect to partial takings for pipeline rights-of-way, the determination of statutory compensation has - as it has for other partial takings such as highways - traditionally involved the discrete consideration of the market value of the interest taken, ${ }^{41}$ and the injurious affection to the remaining lands of the owner as a result of the taking. That has, however, not been the case in Alberta.

\title{
A. EXPROPRIATION COMPENSATION PRINCIPLES
}

The cornerstone of expropriation compensation is the market value of the land having regard to its highest and best use. ${ }^{42}$ The basic and most fundamental principle of compensation in the event of an expropriation of land interests is that the value at the moment before expropriation is the relevant value for establishing the amount of compensation owing. That principle was articulated in a leading case as follows:

\begin{abstract}
The principles upon which compensation is assessed when land is taken under compulsory powers are well settled. The owner receives for the lands he gives up their equivalent, i.e., that which they were worth to him in money. His property is therefore not diminished in amount, but to that extent it is compulsorily changed in form. But the equivalent is estimated on the value to him, and not on the value to the purchaser, and hence it has from the first been recognized as an absolute rule that this value is 10 be estimated as it stood before the grant of the compulsory powers. The owner is only to receive compensation based upon the market value of his lands as they stood before the scheme was authorized by which they are put to public uses. ${ }^{43}$
\end{abstract}

There are therefore two fundamental steps in determining compensation for the taking of an interest in land. The first is to assess the highest and best use to which the lands could reasonably have been put, without regard to the purpose for which they are expropriated, and then fix the compensation to be awarded to the owner based on the market value of the lands at that highest and best use. ${ }^{44}$

The highest and best use of lands is not necessarily their actual or current use. It is the highest and best use to which the lands could reasonably be expected to be put. For instance, lands in agricultural use may in fact be, in whole or in part, ripe for subdivision. However, that assessment must be based on reasonable expectation, and not mere speculation.

The market value of a property is typically determined using the direct sales comparison approach, ${ }^{\text {t5 }}$ as cited in The Lav of Expropriation and Compensation in Canada:

Todd, ibid. at 109-10. Sec also Dell Holdings LId. v. Toromo Area Transir Operating Authority, [1997] 1 S.C.R. 32; Inving Oil v. Canada, [1946] S.C.R. 551 at 556. Adjusted for the residual and reversionary values to the owner of the area subject to the interest taketl. though this is oflen ignored, sometimes as explicilly permitted by legislation. Re Valley Improvement Co and Mesropolitan Toronto and Region Conservation Awthority. [1965] 2 O.R. 587 at 597 (C.A.).

" Re Licas and Chesterfield Gas and Water Board, [1909] I K.B. 16 at 29-30 (C.A.).

" Farlinger Developments lid. v. East York (Borough of) (1975). 61 D.L.R. (3d) 193 (Ont. C.A.) (in other words, the value of the lands taken to a pipeline company for use as a right-of-way is irrelevant). Patson Indusiries Lid. v. Calgan' (City of (1981), 24 L.C.R. 181 at 188 (Alta. L.C.B.); aff (1983). 48 A.R. 272 (C.A.) [Patson]. Other approaches are not preferred by courts and tribunals because they are more complicated and involve more judgmental factors that may detract from faith in the result. Nevertheless. other approaches may have to be considered in circumstances where no sales of reliable: 
The direct sales comparison approach compares the subject property with market data, including the sale prices of comparable properties. From this comparison, and afler making appropriate "adjustments", the appraiser reaches a conclusion as to the price, or range of prices. for which the subject property might have been sold, had it been available for sale, at the date of the expropriation. ${ }^{46}$

The identification of sales of comparable properties is not always a simple matter, particularly when the interest acquired is a partial taking of a kind for which there is effectively no open market of willing sellers and buyers. ${ }^{47}$

In the context of pre-reform expropriation and surface rights legislation, an owner could be dispossessed without any advance payment of compensation and face protracted litigation, plus the whole of his or her legal costs. This typically caused the courts and tribunals to presume voluntary transactions between an owner and an expropriating authority were tainted and not representative of "market value" as the owner did not fit within the statutory definition of a "willing seller." was given little weight. The introduction in Canada of surface rights reform legislation in the 1970 s and 1980s that required, among other things, a pipeline operator to promptly pay an owner the estimated market value of the right-of-way acquired and to reimburse an owner's reasonable legal, appraisal and other costs, has done much to rectify the perceived imbalance between the bargaining power of an operator and an owner. ${ }^{49}$ However, equilibrium still cannot be presumed to have been established between the parties. Indeed, the pendulum in many circumstances is likely to have swung in favour of owners in their negotiations with pipeline operators whose acquisitions are often driven by strict project scheduling, routing requirements and cost considerations.

Arguably the most, and possibly only, reliable sales comparables of lands in which a partial interest is proposed to be acquired for a pipeline right-of-way are other sales of lands

4. comparables are available.

Todd, supra note 10 at 181 . It should be noted that this approach is now referred to as the "direct comparison approach" by the Appraisal Institute of Canada as there are not always sales comparables available (e.g. listings/bona fide offers may sometimes be considered).

" Pipeline easements, for example, are not created by owners and offered for sale on an open market.

* It is a commonly accepted principle that a tribunal must consider and weigh very carefully any evidence it may have of sales to authorities. On this point. Rand J., in Gageroun Lumber Co. Lid. v. Canada, [1957] S.C.R. 44 at 56 [Gagetown Lumber], stated that:

The primary question is of freedom in the negotiation as a fact, and it is for the iribunal, in the light of the circumstances, to say whether the price was infuenced by extraneous elements, of whether the parties were concerned only to reach agreement on a figure deemed to be the fair value of the property [emphasis added].

Sec also Nowellv. Onsario (Minister of Environment) (1984), 30 L.C.R. 255 at 259 (O.M.B.) [Nowell]:

In ruling that the issue as to pre-expropriation sales ... goes to weight and not to admissibility. the board instructed (counsel for the claimant) that his failure to demonstrate that such iransactions were untainted would result in them being disregarded as such sales are inherently. suspect. Although admissible. such sales are presumed to be not free and voluntary and the person introducing and relying upon them must rebut that presumption through evidence of surrounding circumstances [emphasis added].

4) The reforms to surface sights legislation coincided with expropriation reforms stemming from important studies such as the 1973 Alberta Institute of Law Research and Reform's Report No. 12: Expropriation, and the Law Reform Commission of Canada's Working Paper 9: Expropriation (1975) and Report on Expropriation (1976). 
in the same area having the same highest and best use as the titled unit. ${ }^{50}$ As such transactions invariably involve the sale of a fee simple interest, the courts have recognized in the case of partial takings that the assessment of compensation should account for the value of any residual and reversionary interest retained by the owner. ${ }^{\text {st }}$ The concepts of residual and reversionary value were explained by the Alberta Court of Queen's Bench:

J understand residual value to mean that value to the landowner which remains in his hands because of his ability to make some economic use of the land involved in the "taking" during the term of the "taking". An example of this would be the ability of the farmer to farm over the top of a pipeline once the pipe has been buried. I understand reversionary value to mean some value to the landowner which will accrue to him once the "taking" has served its use. An example of this is the well-site which is abandoned after the economically recoverable oil has been extracted. ${ }^{\text {s2 }}$

The quantification of residual and reversionary values is often challenging and has therefore frequently been ignored for lack of reliable evidence. ${ }^{53}$ In the absence of a statutory provision explicitly allowing for residual or reversionary values to be ignored, however, a tribunal or court charged with fixing compensation is required to consider it. ${ }^{5.4}$

In addition to the market value of the lands acquired, another element of compensation for a partial taking is any damages for injurious affection to the remaining lands of the owner. ${ }^{\text {ss }}$ In contrast to the assessment of the market value of the lands taken, the determination of

In a rural setting, for example, pipeline rights-of-way are often acquired from quarter sections having both an agricultural highest and best, as well as actual use. The highest and best use of the titled unit may, however, be different from its actual use, in whole or in part (non-homogeneous highest and best use). For instance, the quarter section might have relatively near-term subdivision potential that is recognized by the market to some degree at the present time. In any event, such comparables are considered more reliable bases for determining the actual economic loss of the owner (subject to adjustments for any residual or reversionary values) than transactions for pipeline right-of-sway interests that do not occur in an open market, are often influenced by extraneous factors and represent the value of lands for use as a pipcline right-of-way. There simply is no such titled unit as a pipeline easement that is freely traded on an open market. Individual owners do not, and indecd cannot, seek regulatory approval for the establishment of pipeline easements across Ileeir property for the purposes of marketing such interests to pipeline companies. And pipeline companies, following approved roules for their pipelines (in respect of which regulalors factor in several oflen competing considerntions such as environmental impacts, econonic efliciency, engineering, public safety, efc.) in effect have very little clooice with respect to the owners from whom they must acquire rights-of-way. Re Cochin Pipe Lines Lid. and Rastray. [1979] 6 W.W.R. 755 at 757 (Alta. Q.B.), rev'd (1981), 27 A.R. 32 (C.A.), leave to appeal to S.C.C. refused (1981). 27 A.R. 359 (S.C.C.) [Cochin]. Justice Haddad commented as follows (at 42) upon the important place of residual and reversionary values in any assessment: "[W]here there exists a residual interest in favour of a landowner the value of the interest, in the course of fixing compensation, cannot be ignored."

s2 Dome Petroleum Lid. v. Grekul (1984), 49 A.R. 256 at para. 29 (Q.B.) [Grekul]

s. It has frequently been argued that a typical failure to adjust to fee simple values for the residual or reversionary value to the owner, coupled with the allowance for loss of use damages, tesults in overcompensation. If reinstatement is the real objective, arguably the "before and after" method would be the most accurate and would also account for any injurious affection to the remaining lands of the owner.

\$4 Cochin, stupra note 51 at 42: "In giving consideration to the residual value the tribunal charged with the duty of fixing compensution must evaluate the evidence to determine such value."

3s Injurious affection damages are frequently, though not necessarily, only available to owners of lands that have been subject to a partial taking. However, in those instances where a remedy is provided to an owner of lands without a taking, based on an explicit or sometimes implicit statutory right, it is typically limited to damages that might otherwise be available pursuant to a civil claim in nuisance. 
damages for injurious affection specifically requires a consideration of the intended use of the expropriated lands. Injurious affection damages are typically measured as the reduction in market value of the remaining lands resulting from the expropriation. The onus for proving injurious affection typically rests on the party claiming it. ${ }^{56}$

\section{B. Federal: SURFACE Rights COMPENSATION JURISPRUdence AND INDUSTRY PRACTICE.}

There is a dearth of judicial authorities concerning the determination of compensation for the acquisitions of interests in lands for pipelines under the $N E B$ Act. The few cases that are available were decided under the $N E B A C l$ before it was substantially reformed in 1983. The approach adopted by the courts ${ }^{57}$ in those cases essentially applied modern expropriation law principles for determining compensation for partial takings. The most commonly referenced case is Re Cochin Pipe Lines Lid. and Rattray. ${ }^{98}$ Speaking on behalf of the Alberta Court of Appeal, Haddad J.A. stated: "In my view, to establish value, he should have adopted the method approved by the Court in the Queen v. Bonaventure Sales Lid. by taking the market value of each quarter section and then applying the per acre value thereof to the land taken by the appellant." ${ }^{.59}$ Justice Haddad also commented upon the important place of residual and reversionary values in any assessment of compensation: "[W]here there exists a residual interest in favour of a landowner the value of the interest, in the course of fixing compensation, cannot be ignored." ${ }^{\circ 0}$ Until recently, there have also been very few decisions of pipeline arbitration committees appointed under the NEB Act after 1983.6 The compensation awards of the pipeline arbitration committees concerning lands located outside of Alberta have had primary regard for the per acre market value of the parcels from which

However, injurious affection, to the extent that it involves an assessment of diminution of market value (as distinct from business losses), can arguably be established as easily by an expropriating authority as the landowner who asserts it.

As discussed in Part II.A, compensation under the NEB Act, before it was substantially amended in 1983, was left to be determined in accordance with certain specified provisions of Railway' Act, which were applied mutuatis mutandis to federally-regulated pipelines. The Raihway $\mathrm{Act}$, which had not been significantly amended since 1919, provided for compensation for the acquisition of lands to be fixed by a superior court judge in the event that a company and an owner did not agree as to the amount of compensation payable. The arbitrator was given virtually no guidance is to how to ascertain the compensalion payable, simply being directed to proceed in such way as he or she deemed best.

Cochin, supra note 51. Justice Haddad specifically rejected the approach to determining compensation followed by the arbitrator to the extent that it involved applying a "small parcel" premium to the per acre market value of the quarter section. The approach enunciated by lladdad J.A. was in keeping with the highway expropriation case of The Queen v. Bonaventure Sales Lid. (No. 2) (1981), 22 L.C.R. 164 (Alta. C.A.), subject to the additional consideration of residual and reversionary value. See also Re Interprovincial Pipe Line Co. [1955]O.W.N. 301 (C.A.). There was a recognition in Cochin that there were no reliable comparables avaitable other than those of the parcel from which the pipeline right-ofway was taken.

Ibid. at 39. This approach coincides with the approach recommended by the LRCC on Expropriation. supra note 17 at $22-23$.

Ibid. at 42.

"The derarth of pipeline arbitration conmmittee decisions is compounded by the policy of the Minister of Natural Resources and the Pipeline Arbitration Secreturiat, who administer the compensation arbitration process under the $N E B$ ACt, to treat arbitration decisions as confidential, nolwillistanding that nothing in the NEB $A c t$ requires such confidential treatment and that any appeal to the Federal Court on a question of law or jurisdiction would inevitably put an arbitration decision and hearing record in the public domain. 
rights-of-way were taken.$^{62}$ However, with the exception of several decisions concerning the Alliance Pipeline Ltd. rights-of-way, which are discussed below, most pipeline arbitration committee awards concerning rights-of-way in Alberta have reflected evidence of "patterns of dealings." This approach has gained acceptance in the Alberta courts for determining compensation under the provincial surface rights legislation. ${ }^{63}$ None of the pipeline arbitration decisions have been considered by the Federal Court of Canada, though appeals from the decisions concerning Alliance Pipeline Ltd. have been initiated.

For the most part, industry practice has been to follow the approach set out in Cochin, though typically without any adjustment to the owner for the residual value of the land imprinted with a pipeline right-of-way. ${ }^{04}$ In the result, owners are typically paid an amount based on the per acre market value of the parcel within which the right-of-way is located. However, there are some notable exceptions to this practice. Reflecting the prevailing practice of operators of provincially regulated pipelines in Alberta, who are governed in their compensation practices by the Surface Rights Act, operators of federally regulated pipelines have often paid amounts for rights-of-way based on "patterns of dealings."

\section{Alberta: SuRface Rights COMpensation JuRisprudence AND INDUSTRY PRACTICE}

Compensation for provincially regulated pipeline rights-of-way in Alberta is predominantly determined on the basis of evidence of so-called "patterns of dealings":

[R]esort is increasingly made to unconventional types of "comparables" as measuring lools for determining compensation either under the specific heads or as a lump sum package, usually referred to as a "global

Some available pipeline arbitration committee decisions have not been concerned with compensation for the acquisition of a right-of-way. See e.g. Pipeline Arbitration Committee Award and Reasons for Decision. Houle and TransCanada Pipelines Limited (24 March 1995) (Ontario). Several decisions clearly relied on the per acre market value of the parcel from which the right-of-way was acquired. See e.g. Pipeline Arbitration Commiltee Award and Reasons for Decision, Burke and TransCanada Pipelines Limited (1 February 1996) (Ontario); Pipeline Arbitration Committee Award and Reasons for Decision. MacDonald and Maritimes \& Northeast Pipeline (7 May 2002) (Nova Scotia): Pipeline Arbitration Commintee Award and Reasons for Decision. Hull and Maritimes \& Northeast Pipeline (1I August 2003) (Nova Scotia).

One decision reflected "pattern of dealings" evidence advanced by the pipeline operator on the basis that it exceeded the per acre market value of the parcel from which the right-of-way was acquired. See Pipeline Arbitration Committee Award and Reasons for Decision, Yanke and Express Pipeline Lid. (14 June 2001) (Alberta). Not discussed here are so-called "Consent Arbitration Awards" that merely document a settlement between the parties. See Consent Arbitration Award Reasons for Decision. Milkovich and Federated Pipe Lines (Northern) Lid. (30 August 1999) (Alberta); Consent Arbitration Award Reasons for Decision, Winter and Federated Pipe Lines (Northern) Lid. (30 August 1999) (Alberta).

Supra note 51. There is, however, an implicit, if still imprecise, recognition of the significant seversionary value to the owner reflected in the amounts paid for areas of temporary work space acquired solely for construction.

These payments have sometimes been supplemented by an amount equivalent to the entry fee required to be paid by provincially regulated pipeline operators, notwithstanding that there is no such requirement under the NEB ACt. Furthermore, in the case of Foothills Pipelines Limited, annual payments have been made in connection with its rights-of-way starting in the early 1980 s in accordance with the methodology used by NOVA Gas Transmission Ltd. in Alberta. For further discussion regarding that methodology, which has not been followed by industry, the Alberta Surface Rights Board or the courts in Alberta, see Part III.C. 
amount." There is no statutory basis for awarding compensation as a "global amount." However, as noted above, such amounts may be fixed as a result of bargaining between groups of landowners and one or more operators and become the basis of subsequent compensation awards in other cases.

The unconventional "comparables" take the form of (i) individual settlements or deals between other landowners and the same or different operators; (ii) a pattern of individual settlements or deals; or (iii) an area agreement reached on behalf of a number of landowners with one or more operating companies. ${ }^{66}$

The 1978 Alberta Court of Appeal case of Livingstone v. Siebens Oil \& Gas Ltd. ${ }^{67}$ is frequently cited as the leading case for the reliance of "patterns of dealings" evidence for determining surface rights compensation in Alberta, though such evidence already had a substantial pedigree with the courts and surface rights tribunals in Alberta by that time. ${ }^{68}$ The case dealt with surface leases for well sites, in which ongoing loss of use and adverse effects were recognized having regard to the operator's exclusive occupation of the surface. The Court of Appeal acknowledged that little weight could be given to evidence of other individual deals, recognizing that an operator may for various reasons pay more than it thinks is fair. However, the Court, alluding to the SRB's reasoning in an unrelated pipeline right-ofway case, found that "pattern of dealings" evidence ought to be considered only in the absence of conventional market value evidence, held that:

\begin{abstract}
The Board is not bound to set compensation at the same amount as is offered by the oil company for there may be reasons for the companies offering higher prices than they think they are bound to pay; it is a matter to be weighed by the Board. However, where there are such a number of deals established so that it may be said that a pattern has been established by negotiations between the landowners and oil companies in a district, then the Board should only depart from such compensation only with the most cogent reasons. ${ }^{69}$
\end{abstract}

Historically, in the context of expropriation law, there has been a presumption that voluntary deals made by expropriating authorities are inherently suspect. ${ }^{70}$ This presumption has largely been ignored by the Alberta courts, which regard "patterns of dealings" as the most cogent evidence in determining surface rights compensation. The Alberta courts' reasoning on surface rights compensation is even more questionable in light of "pattern of dealings" evidence being inextricably linked with the concept of "global awards." These awards incorporate, without specifying their nature or their amounts, other heads of damages besides the value of the land taken. This is exemplified by two of the most frequently referenced cases in Alberta wherein "pattern of dealings" evidence was relied upon for

Todd, supra note 10 at 443.

(1978), 8 A.R. 439 (C.A.) [Livingstone].

See Twin Oits Lid. v. Schmidt (1968), 74 W.W.R. 647 (Alta. Dist. Cl.), where "pattern of dealings" evidence was relied upon to confirm an assessment of compensation based on individual heads of damages; Great Plains Development Co. of Canada v. Lyka. [1973] S W.W.R. 768 (Alta. S.C. (A.D.)). rev'g |1972] 6 W.W.R. 321 (Alta. Dist. C1.), where "paltern of dealings" evidence was considered in the absence of other credible evidence of land values. See generally Roen v. PanCanadian Petroleum Lid. (1977), 6 A.R. 70 (Alta. Dist. Ct.).

(19) Livingstone, supra note 67 at 445.

Ii" Giles v. Nove Scotia Housing Commission (1976), 11 L.C.R. 263 at 275 (N.S.E.C.B.); Gagetown Lumber, supra note 48 at 56; Nowell, supra note 48 at 259; Kerr v. Minister of Transportation (No. 1) (1980), 20 L.C.R. 67 at 77 (Alta. L.C.B.). 
determining pipeline right-of-way compensation, namely Petryshyn v. Nova, An Alberla Corporation ${ }^{71}$ and NOVA, An Alberta Corporation v. Bain. ${ }^{72}$

From the perspective of expropriation law and the underlying principle of economic reinstatement, one need look no further for an indictment of "pattern of dealings" evidence and the fallacies upon which it is founded than the reasons typically given in support of that approach. For example, the Alberta Court of Queen's Bench in Dome Petroleum Lid. $v$. Richards, ${ }^{73}$ a case concerning so-called "area agreements," stated:

The beauty of area agreements, to my mind, is that all landowners are treated equally when it comes to compensation (with a few logically acceptable variations) and seem more content to share their land surface rights with the operators involved. If we are charged, under the ACI, to look for a true willing buyer-willing seller yardstick of measurement for the "taking", it seems to me that these area agreements come closest to fulfilling this criterion. ${ }^{74}$

\section{The Court went on to say that great weight should be given to "area agreements"}

where it can be shown that they represent a true arm's leng(h) negotiation between owners and operators bargaining on an equal footing. I do not believe that any tribunal should, under the $A c t$, be permitted to exclude such evidence. What may always be at issue is the amount of weight to be attached to the same. To my mind I would hold that even one example of an "area agreement" frecly negotiated should be regarded as highly relevant and cogent evidence for the reasons already advanced. It should centainly be accorded more weight than several negotiated leases between individual landowners and an operator or operators. especially if these were signed early in the oil development of a particular area. In addition. I would hold that a compensation tribunal should not be too restrictive in its interpretation of the geographical tength and breadth of the area to be affected by an "area agreement". Once one or more area agreements have been negotiated it seems $10 \mathrm{me}$ that it would be in the interests of both sides, both from a cost approach and. from the point of vicw of happy relationships between landowners and operators, that some uniformity emerge so that operators may know in advance what their costs will be to obtain surface entry rights and landowners will know that they are being treated the same as others in like circumstances. There will, of course, always be unusual situations which depant markedly from the norm and these will be dealt with by the Board or the court as they arise. ${ }^{75}$

Factors that are given as justification for surface rights decisions in Alberta, such as the purchasing of peace with a broad group of landowners, and evidence that an operator, in the face of organized opposition, is a proxy for an open market, would in an expropriation context be irrelevant considerations.

(1982), 23 Alla. L.R. (2d) 193 (C.A.). The Court held that a compensation award based on "pattern of dealings" evidence does not require a separate consideration of residual and reversionary values (which, in any event, can now be iguored) as the parties are presumed to have laken them into account.

(1985). 36 Alta. L.R. (2d) 289 (C.A.). This case is notable in that a pattern of freely negotiated agreements was found to exist notwithstanding cvidence that the right-of-way agreements were tainted by undue pressure on the pipeline operators involved.

(1985). [ 1986] 66 A.R. 245 (Q.B.), additional reasons (1986), 69 A.R. 139 (Q.B.) [Dome Petroleum] Ibid. at para. 250.

Ibid. at para. 26I. The Court went on to state that only in the absence of area agreements or clear pattern of dealings evidence would it be appropriate to resort to other evidence, presumably including markel value evidence established in accordance with conventional methods. 
That said, it should be recognized that the language of the Surface Rights $A C t^{70}$ is permissive in nature with respect to the factors that can be considered in determining compensation and leaves latitude for judicial rule making and policy considerations.

There are no doubt some practical advantages inherent in the reliance on "pattern of dealings" evidence. It is foremost a simple, albeit simplistic, approach for determining compensation and does not require the expertise of appraisers." Such simplicity has the potential to reduce the costs incurred to administer a pipeline operator's land acquisition program (though at the expense of having to pay higher prices for land rights). Furthermore, it has the appeal of being palatable to owners who are often concerned about whether they are being paid the same compensation as their neighbours. ${ }^{78}$

It should also be noted that legislation such as the Surface Rights $A c t$ requires a pipeline operator to pay an advance of the compensation offered to an owner before exercising its right of entry ${ }^{79}$ and provides that the owner will recover his or her reasonable costs of compensation proceedings. These reforms have to a significant degree diminished the spectre of expropriation as a reason for an owner to accept under-compensation.

On the other hand, it remains that agreements between pipeline operators and owners are inevitably influenced by extraneous factors. ${ }^{80}$ Pipeline proponents' project requirements create significant incentives to overcompensate owners. To start, there are the practical considerations noted above. As well, pipeline operators are severely restricted in their selection of lands by pipeline routing requirements. ${ }^{81}$ Furthermore, commercial considerations often require the timely completion of pipeline operators' land acquisition programs. ${ }^{R 2}$ And the costs of expropriation - in terms of delay, expropriation proceeding expenses and adversely affected relationships with owners - are borne almost exclusively by the pipeline operator.

$\boldsymbol{*}$

Supra note 2, s. 25(1) sets out the factors that the SRB may consider in determining compensation payable. This is not true of most expropriation legislation, nor the NEB ACI. supra note 4.

7 Indeed. appraisers, in the preparation of sile-specific land appraisals, examine closely the highest and best use of a subject property and look behind the transactions of comparable lands to assess whether the amount paid ought to be adjusted, up or down, for any extraneous influences. Dome Petroleum, supra note 73 at paras. 250, 261: Sandboe v. Coseka Resources Lid. (1987), 79 A.R. 386, rev'd (1989), 94 A.R. 330 (C.A.).

7. Supra note 2, 5. 19. In Albena, the "entry fee" "is in addition to any compensation payable in respect of the right of entry." expropriating authority.

Pipeline routing is often determined by a number of competing considerations. However, the starting point is typically the shortest available route between the desired receipt and delivery points on the assumption that it represents the best route in terms of both costs and environmental impacts. The added material and construction costs associated with a longer roule often exceed the polential added land acquisition costs. Furthermore, pipeline regulators typically expect pipelinte proponents to locite pipelines, to the degree reasonably possible, within areas that have previously been disturbed by agricultural development or other linear developments.

m: pipeline project is often contingent on timely completion. Furthermore. shippers' iransportation commitments may be contingent on a pipeline being in service by a particular date. Additionally. project financing may be contingent on a pipeline proponent's substantial completion of its land acquisition requirements. 
Such obvious concerns in connection with "pattern of dealings" evidence are not overcome by the sheer number of agreements negotiated in a given area. Indeed, a large number of agreements, or an "area agreement," providing an identical rate of compensation to owners over an extensive area reflects a paramount concern with perceptions of equity as between owners as opposed to the actual equal treatment of owners. Ostensibly, the purpose of compensation is not to pay everyone the same amount for acquired interests in land, but to economically reinstate each individual owner having regard to his or her actual loss. ${ }^{83}$

Perhaps the most illustrative example of these types of influences at work is the annual compensation program instituted by NOVA, the owner and operator of the principal gas transmission system in Alberta, in connection with its pipeline rights-of-way acquisitions in agricultural areas starting in the early 1980 s. $^{85}$

The NOVA program ${ }^{86}$ had at its core the assessment of fee simple land values generally in accordance with conventional expropriation and appraisal principles, ${ }^{87}$ and involved the annual payment of a prescribed percentage of the per acre fee simple land value, subject to review by private arbitration, if necessary, every five years. The program was devised in the face of political pressure and organized landowner opposition during a period of high inflation, high interest rates and cost-of-service regulation. NOVA also found itself repeatedly before the SRB because of area pricing established by small oil and gas operators anxious to get their production tied in. The effect of the program, which is ongoing given its broad acceptance by the owners to whom it was offered over a span of approximately 20 years, was to require NOVA to pay the owner the fee simple value of the lands within the right-of-way every five years for the life of the pipeline. ${ }^{88}$

Notwithstanding its prevalence in the province of Alberta, the NOVA program has not been followed by industry, and the SRB and the courts have to date had the good sense not to accept it as evidence of a "pattern of dealings" for the purposes of determining

"2t Strictly speaking, this would probably entail the use of the "before and after" method for assessing an owner's loss for a partial taking. See supra note 5.

". Formerly Alberta Gas Trunk Line Company Limited, then NOVA, An Alberta Corporation (name change effective 19 August 1980). subsequenily NOVA Corporation of Alberna (name change effective I Seplember 1987), subsequently NOVA Gas Transmission L.td. (NGTL) (name change eflective II May 1994). now a wholly owned subsidiary of TransCanada Pipelines Limited. The NGTI, facilities in Alberia continue to be provincially regulated.

*s The NOVA annual payment program (which was only offered in connection with agricultural lands, and not country residential, commercial or industrial lands) was introduced late in $198 \mathrm{I}$ and involved annual payments based on prescribed percentages of the per acre market value, as determined by an accredited appraiser, of the parcel within which the right-of-way was situated. First year compensation for the rigltt-of-way consisted of a one-time payment of 50 percent of the per acre market value. In the second and subsequent years, an annual payment equal to 20 pereent of the per acre market value was paid. subject to review every five years.

*h. It, or more precisely a modified version, has been at the core of the recent claims by owners for annual compensation for pipeline rights-of-way under both the provincial Surface Rights $A c t$ and the federal NEB ACA.

*7 Though without any allowance for residual or reversionary value to the owner.

* The program was also instituted by the federally regulated Foothills Pipe Lines Ltd. in the context of the acquisition of lands for the pre-build portion of the Arctic gas pipeline in Alberta. It is notable that the Foothills land program was administered by the NOVA land department at the time. NOVA had a 50 percent ownership stake in Foothills 
compensation under the Surface Rights Acl. However, it really is only a more extreme example of how the amounts paid by operators for voluntary right-of-way acquisition are inherently suspect, being influenced by extraneous factors.

General industry practice in Alberta has invariably been guided by the preponderance of the jurisprudence in Alberta, which, as noted, has in turn simply reflected industry practice. There is, at this juncture, no escaping the determination of compensation based on "pattern of dealings" evidence in Alberta, at least in the context of provincially regulated pipeline rights-of-way across agricultural lands. In some agricultural areas, right-of-way pricing has remained static for many years, which is not surprising given that it typically significantly exceeds the per acre fee simple value of the lands within which rights-of-way are situated. ${ }^{R ?}$

\section{AnNual Comprensation}

\section{A. FEDERAL: $N E B$ ACT}

Under the $N E B A C l$, an owner is given an election as to the method of payment of the compensation he or she is entitled to, whether pursuant to an agreement for the acquisition of lands or an award of compensation made by a pipeline arbitration committee. ${ }^{90}$ For example, s. 98 of the $N E B A C t$ provides that a pipeline arbitration committee shall, in making an award of compensation to an owner, direct "the compensation or such part of it as is specified by that person be made by one lump sum payment or by annual or periodic payments of equal or different amounts over a period of time." To date, there has been no judicial interpretation of the rather convoluted wording of s. 98; however, a pipeline arbitration committee specifically seized of the issue in connection with the Alliance Pipeline has recently rendered its decisions."

\section{Al.liance Pipleline Land acQuisition Cl.aims}

The Alliance Pipeline ${ }^{92}$ comprises approximately $2,990 \mathrm{~km}$ of natural gas mainline $\mathrm{e}^{93}$ and

Its application, which is most prevalent in agricultural areas, is not always straightforward, particularly: in proximity to urban areas where fee simple land values approach or even exceed right-of-way pricing in agricultural areas. In such cases, operators may resort to the conventional land valuation approach. though agreements inevitably result in premium compensation as a result of various extraneous considerations.

NN NEB ACt, supra note 4, ss. 86.98.

"See e.g. Pipeline Arbitration Committee Award of Compensation and Reasons for Decision. Byron But and Alliance Pipeline Lid. (5 September 2003).

92 The authority to construct and operate the Canadian portion of the Alliance Pipeline was granted by the NEB pursuant to Part III of the NEB ACt, supra note 4. After a 77-day public hearing. the NEB issued its Reasons for Decision in the Matter of Alliance Pipelime L.td. on Behalf of Alliance I'ipeline Limised Parinership. Alliance Pipeline Project (November 1998). GH-3.97 at xviii(NEB), which. among other things, concluded that "Alliance's proposed land requirements for permanent right-of-way and temporary work space ... were reasonable and justificd," and that the pipeline wass required for public convenience and necessity. Alliance received formal Board approval for the Pipeline on 26 November 1998 pursuant to Board Centificate GC-98. Board Certificale GC.98 was approved by the (iovemor-inCouncil by Order in Council, P.C. 1998-2176, C. Gaz. dated 3 Decernber 1998

9: The mainline pipeline portion of this system ranges from 36 in $(914 \mathrm{~mm}) 1042$ in $(1067 \mathrm{~mm})$ int diameter. 
$698 \mathrm{~km}$ of lateral pipelines ${ }^{94}$ extending from gathering points in northeast British Columbia and northwest Alberta to a delivery point near Chicago, Illinois. The Canadian portion of the system, totalling approximately $2,257 \mathrm{~km}$ of pipelines, was constructed between June 1999 and November 2000, and ends at the Canada-U.S. border crossing near Elmore, Saskatchewan.

Alliance's land acquisition program was initiated well in advance of the commencement of construction. Under the $N E B A C t$, a pipeline company that requires lands for the purposes of a section or part of a pipeline is required to serve notice on the owners of such lands describing, among other things, the lands required by the company, the procedures for approval of the detailed route of the pipeline, the value of the lands required and details of the compensation offered by the company. ${ }^{95}$ Alliance was therefore required to served notice on each of the owners of lands along its planned pipeline route in Canada of its requirement of permanent rights-of-way and temporary work spaces. ${ }^{20}$

The basis for Alliance's offers of compensation set out in its notices was the per acre market value of the subject lands. ${ }^{97}$ Alliance offered the full per acre market value for each acre of permanent right-of-way and half of the market value for each acre of temporary work space, which was only acquired for a period of two years from the start of construction. The compensation offers set out in Alliance's 87 notices did not account for the residual and reversionary value to the owners of the rights-of-way, but implicitly recognized the significant reversionary value to the owners of the lands acquired for construction purposes only. In accordance with the $N E B A c t$, the owners were given an-election to take the compensation offered as a lump sum, or by annual or periodic payments (by simply dividing the lump sum amount over the number of years over which payments were to be made).

Alliance also made further lump-sum-only offers of compensation to owners for the purposes of settlement and right-of-way acquisition by agreement that typically significantly exceeded the estimated market value of their lands. In Alberta such offers were based upon, in part, the amounts paid by other pipeline companies operating in the area of the owners' lands, including provincially regulated companies that are required to pay a supplemental $\$ 500$-per-acre entry fee under the Alberta Surface Rights Act. Alliance's rationale for making these further offers was, among other things, to complete its land acquisition program in a timely manner having regard to commercial considerations such as financing conditions and in-service date commitments; to avoid costly construction delays and "move-arounds" 18 and to avoid costly and adversarial expropriation and arbitration proceedings. In so doing, it

The lateral pipelines, which gather gas from 40 collection points in northeast B.C. and northwest Alberta, range from 4 in $(114 \mathrm{~mm})$ to 24 in $(610 \mathrm{~mm})$ in diameter. NEB Act, supra note 4, s. 87.

Temporary working spaces are typically strips of land paralleling pipeline rights-of-way and are required solely for the purposes of initial construction (e.g. temporary topsoil and spoil pile storage. equipment bypass lane, etc.), and not the ongoing operation and maintenance of the pipelinc. Additional discrete areas of temporary working space are oflen acquired at road, utility and river crossings where the construction footprint is larger. In other words, if the market value of a 100 acre tilled unit is $\$ 100,000$ (not including any amount for improvements such as buildings), then the per acre bare land market value is $\$ 1,000$.

4) "Move-arounds" involve the leapfrogging of the pipeline construction equipment train around lands through which rights-of-way have not been acquired. "Move-arounds" are typically very expensive propositions hecause of the cosis associaled with remobilizing equipment to an isolated location. 
recognized that it would, as a practical matter, have to pay owners amounts they were accustomed to receiving from provincially regulated companies in Alberta (including a supplemental \$500-per-acre entry fee under the Alberta Surface Rights Act), notwithstanding that such amounts typically represented a significant premium over the conventionally determined market-value-based compensation that they might be entitled to under the $N E B$ Act.

The majority of owners in Alberta opted to enter into land acquisition agreements for amounts based on an assessment of area pricing for pipeline rights-of-way, or a "pattern of dealings." A number of owners, however, did not. In those instances, Alliance was required to apply to the NEB for right-of-entry orders ${ }^{99}$ and to pay to the owners an advance of compensation..$^{100}$

A number of owners sought to have their compensation claims determined under the $N E B$ Act. ${ }^{101}$ Accordingly, the owners served notices of arbitration upon the Minister of Natural Resources (Minister) and Alliance pursuant to $\mathrm{s} .90$ of the $N E B$ Act. ${ }^{102}$ As required by s. 91 of the NEB ACt, the Minister appointed pipeline arbitration committees, and in turn, served the notices of arbitration upon them.

NEB Act, supra note 4, s. 104. See also the National Energy Board Rules of Practice and Procedure. 1995, S.O.R./1995-208, Part V (which sets out the notice, application and written hearing process for the acquisition of lands by right of entry order).

$N E B A C t$, supra note 4, s. 105 (which sets out the requirement to pay an advance of compensation prior to exercising a right of entry). Unlike the Surface Rights $A c t$, which requires the operator to pay 80 percent of its last offer, there is no guidance set out in the NEB ACt as to the appropriate amount of an advance. Given the range of payment options available to an owner under s. 98 of the NEB ACt, the determination of an appropriate advance may require some knowledge as to what the owner is requesting. Alliance adopted a policy of paying 100 percent of the conventionally determined market value of the lands for rights-of-way and 50 percent of that amount for temporary working spaces. Under s. 105 of the $N E B A C t$, an owner can request an arbitration hearing to determine the amount of the advance. Two cases proceeded to arbitration and were appealed by Alliance to the Federal Cour, Trial Division (see Alliance Pipeline Lid. v. Fast. 2003 FCT 642 and Alliance Pipeline Lid. v. Bokenfohr. 2003 FCT 641). In both cases. Alliance was required to pay as an advance its settlement offers based on "pattern of dealings" evidence, including a supplemental amount for the Alberta entry fee. Then later, in the final determination of compensation payable under the NEB Acr to the first owner, the same Pipeline Arbitration Committee reversed its decision and disallowed the claim for the Alberta entry fee. Where a company and owner cannot reach an agreement as to the amount of compensation payable under the $N E B$ ACt for the acquisition of lands or for damages suffered as a result of construction of the pipeline, the company or the owner may request the matter to be negotiated or arbitrated under ss. 88 and 90 of the NEB Act. The functions of negotiation and arbitration under the NEB Act fall within the ambit of the Minister. 


\section{Relevant NEB aCt Provisions}

The factors that the Pipeline Arbitration Committee was required to consider $^{103}$ in determining compensation for the acquisition of lands ${ }^{104}$ under the $N E B$ Act are set out in $\mathbf{s}$. 97, which provides, in the relevant part, as follows:

97(1) An Arbitration Committee shall determine all compensation matters referred to in a notice of arbitration served on it and in so doing shall consider the following factors where applicable:

(a) the market value of the lands taken by the company:

(b) where annual or periodic payments are being made pursuant to an agreement or an arbitration decision, changes in the market value referred to in paragraph (a) since the agreement or decision or since the last review and adjustment of those payments, as the case may be;

(d) the adverse effect of the taking of the lands by the company on the remaining lands of the owner;

(2) For the purpose of paragraph (1)(a), "market value" is the amoum that would have been paid for the lands if, at the time of the taking, they had been sold in the open market by a willing seller to a willing buyer. ${ }^{\text {us }}$

When a pipeline arbitration committee makes an award of compensation, that is not the end of the matter. An owner in favour of whom an award is made is then entitled to make an election as to how the award should be paid. The NEB ACt provides as follows:

98(1) Where an Arbitration Committec makes an award of compensation in favour of a person whose lands are taken by a company, the Committec shall direct, at the option of that person, lhat the compensation or such

The factors to be considered by a pipeline arbitration committec must be read in the context of the restricted application of the following compensation provisions of the NEB ACr:

84 The provisions of this Part that provide negotiation and arbitration procedures to determine compensation matters apply in respect of all damage caused by the pipeline of a company or anything carried by the pipeline but do not apply to

(a) claims against a company arising out of activities of the company unless those activities are directly related to

(i) the acquisition of lands for a pipeline.

(ii) the construction of the pipeline, or

(iii) the inspection, maintenance or repair of the pipeline;

(b) claims against a company for loss of life or personal injury; or

(c) awards of compensation or agreements respecting compensation made or entered into prior to March I, 1983. this Act or a Special Act, and includes real property, messuages, lands, tenements and hereditaments of any tenure, and any easement, servitude, right, privilege or interest in, to, on, under, over or in respect of the same").

Ibid, s. 97 [emphasis added]. Other factors that shall be considered by a pipeline arbitration committec come under the rubric of damages suffered as a result of the operations of the company, as distinct from compensation for the acquisition of lands, including: "(c) the loss of use to the owner of the lands taken by the company": "(e) the nuisance, inconvenience and noise that may reasonably be expected to be caused by or arise from or in connection with the operations of the company: $(f)$ the damage to the lands in the area of the lands taken by the company that might reasonably be expected to be caused by the operations of the company: (g) loss of or damage to livestock or other personal property affected by the operations of the company; (h) any special difficulties in relocalion of an owner or his property": and "(i) such other factors as the Committee considers proper in the circumstances." 
part of it as is specified by that person be made by one lump sum payment or by annual or periodic payments of equal or different amounts over a period of time. ${ }^{100}$

\section{Pipeline Arbitration Committee Decisions}

On 5 September 2003, the first of the pipeline arbitration committees, appointed by the Minister to hear and decide the owners' claims for compensation for the acquisition of lands, rendered 14 decisions in relation to the claims of 12 different owners. ${ }^{107}$

The majority of the subject properties - located in the Peace River Region of Alberta and the area between Lamont and Strathcona near Edmonton - had an agricultural highest and best use, though some lands were still forested. The one exception was a property near Edson, Alberta, which was assessed to be in transition from agricultural to highway commercial highest and best use.

The owners' claims for compensation for the acquisition of lands, with a few exceptions, were framed as follows:

For the purposes of compensation, there should be no distinction drawn between areas of permanent right-of-way (required for the initial construction and long-term operation and maintenance of the pipeline) and temporary working space (required only for the initial construction of the pipeline) taken by Alliance. The basis for this view was that, notwithstanding the very different rights actually acquired in the respective areas and the NEB's determinations that Alliance's proposed land requirements were reasonable, Alliance was deemed by the owners to have acquired insufficient areas of permanent right-of-way for the long-term operation and maintenance of its pipeline. Furthermore, in the case of forested lands, the temporary working space was permanently altered by the removal of the trees for construction;

The compensation for rights-of-way ought to be based on a modified version of the annual compensation program instituted by NOVA ( 50 percent of the per acre market value of the lands in the first year, and 20 percent each following year, to be reviewed every five years), which represented the only annual payment program for pipeline rights-of-way in the "market place."

The market value used in the formula should not, however, be that of the titled unit as is the custom in the NOVA program. Instead, both the wording of the $N E B A C t$ - the s. 97(I)(a) requirement to assess the "market value of the lands taken" - and some case law ${ }^{108}$ require the consideration of reliable small-parcel comparables, if available. Transactions for pipeline

lbid., s. 98 [emphasis added].

In a few cases, the Pipeline Arbitration Conmittee was also required to consider compensation claims for damages arising from construction, such as: loss of use (e.g., crop. pasture or tree losses); nuisance (e.g., in the construction damages context, interference with farming operations during temporary severance of fields): inconvenience and noise; damage to the lands taken (e.g. 1opsoil admixing): and adverse effects to the remaining lands (i.e. injurious affection)

Cochin, supra note 51: Patson, supra note 45. 
easements were argued to constitute such reliable small-parcel comparables (the "pattern of dealings" amount paid in the area for pipeline easements by provincially regulated pipeline operators, as well as by Alliance) ${ }^{109}$ Alternatively, if no "pattern of dealings" for pipeline easements could be determined, sales of small country residential parcels constituted reliable comparables (notwithstanding the substantially different highest and best use of the lands and property rights) solely on the basis that they were of approximately the same acreage as rights-of-way transecting a quarter section. In any event, an annual payment resulting in compensation having a present value exceeding compensation for the taking as a lump sum was warranted because of speculative and unquantifiable ongoing interference of the pipeline with an owner's use of his or her lands, which should be factored into the compensation for the acquisition of the right-of-way as a "global award";"10

The compensation for land acquisition is a broader undertaking than simply assessing the market value of the lands acquired, and should account for various other factors such as alleged, but unquantifiable, ongoing adverse effects and injurious affection under s. 97(1)(d) and the catch-all "other factors" under s. 97(1)(i) (that is, a "global award");

The "controlled area" created by s. 112 of the $N E B A c t$, which extends $30 \mathrm{~m}$ to each side of Alliance's permanent rights-of-way, ought to be treated, for purposes of compensation, the same way as the permanent rights-of-way."' In effect, the "controlled area" constitutes a de facto taking. That particular element of each claim was later amended to instead seek compensation for the "controlled area" on the basis that it injuriously affected the remaining lands of the owner (see Part V.A); and

Alliance should be required to pay the equivalent of the $\$ 500$-per-acre entry fee required to be paid by provincially regulated pipeline operators under the Alberta Surface Rights Act on all lands acquired as permanent easement or temporary working space on the basis that it constituted "compensation."

Alliance's response to the compensation claims for land acquisition can be summarized as follows:

- Compensation for land acquisition in the surface rights context is principally the same as it is in the expropriation context, and therefore is foremost a function of

Though it was recognized even in the owners' expert's hearsay evidence of "pattern of dealings" that the amounts paid for easements are considered by industry to exeed the market value of the lands acquired and to include a "signing bonus."

110. Further support for the proposition that the $N E B A C$ contemplated perpetual land payments was drawn from the House of Commons Debales during the second reading of Bill C. 60 to amend the NEB Acf (sec House Debates, supra note 17 at 8006): "Owners whose lands will be taken will be given the option as to whether they prefer to receive periodic payments, in the nature of a land rental, with the right to have the amount of these payments reviewed al five-year intervals."

III The Pipeline Arbitration Committec was originally precluded from considering the "controlled area" for purposes of compensation. The matter was eventually referred to the Pipeline Arbitration Committee as a matter that it could consider in terms of injurious affection to the remaining lands of the owners.

See below for further discussion. 
assessing the "market value of the lands taken." A consideration of the wording of the $N E B A c t$, the regulations that dictate the kind of evidence of land values that a pipeline operator must file, expropriation principles and case law all indicate that compensation for permanent rights-of-way and temporary working spaces should be based on the appraised per acre market values of the subject titled units (as bare land), having regard to their highest and best use, less any residual and reversionary values of the rights-of-way and temporary working spaces to the owners. Injurious affection to the remaining lands must also be considered; ${ }^{112}$

- The duty to give adequate reasons requires a pipeline arbitration committee to consider and assess each head of compensation separately, thus precluding a "global award." 113 An award of compensation for the acquisition of lands should, in any event, not include any amount for matters properly characterized as damages arising from construction or operations. Furthermore, there is no need to make allowances for speculative damages in advance of their occurrence having regard to the requirement on the pipeline company to compensate for such damages when they occur, and the availability of further arbitration if the company and owner cannot come to terms on the amount of that compensation; ${ }^{114}$

The "pattern of dealings" approach, which is settled law in Alberta under the more permissive Surface Rights $A C t$, is a "global award" and does not provide reliable evidence of "the market value of lands taken" for the purposes of the NEB Act. Nor do small country residential parcels constitute reliable analogs for pipeline easements. Either approach fundamentally ignores the actual value of the owner's lands having regard to their highest and best use. The amounts paid by Alliance for easement agreements were irrelevant as they: constituted lump sum settlement offers based on the "pattern of dealings" for pipeline easements paid by provincially regulated pipeline operators; were supplemented by the equivalent of the provincial

Cochin, supra nole 51 . See also Procedure Rules, supra note 21 , ss. $4(1)(\mathrm{g})$ and $8(1)(\mathrm{h})$, which require that the pipeline company's notice of arbitration, or reply, shall:

be accompanied by an appraisal report showing all the facts taken into account by the company in arriving at the amount of the compensation offered for the lands and stating, where applicable,

(i) the value assigned by the company to the lands exclusive of the improvements to, or things grown on the lands. including a consideration of the curtent use of the lands, the zoning, the developments projected and any other factor that might affect the lands,

(ii) the value assigned by the company to the improvements to and things grown on the lands, and

(iii) the estimated amount of the damage to the remaining lands of the owner. decisions in writing and containing reasons. See also Grekul, supra note 52; Canadian Natural Resources Lid. v. British Columbia (Medialion \& Arbitration Board), [2002] B.C.J. No. 2505 (S.C.) (QL); Andrews v. Grand \& Toy Alberta L.dd. (1978), 64 D.L.R. (3d) 663 at 679 (Alta. C.A.) and [1978] 2. S.C.R. 229 at 236 . In discharging its administrative duty 10 give adequale reasons for its decisions, a pipeline arbitration committe must arguably specifically address each of the enumerated factors and, at the very least, provide an explanation as to why they are inapplicable in the given circumstances. Adoption of "pattern of dealings" evidence, which purports to effect a global accounting of the types of factors enumerated in $\mathrm{s} .97$ of the NEB ACt, would arguably constitute a dereliction of the duty to specifically consider each factor. 
\$500-per-acre entry fee; significantly exceeded the per acre market value of the subject titled units having regard to their highest and best use, even before taking residual or reversionary values into account; and were influenced by extraneous factors (such as the desire to avoid costly delays from both commercial and construction perspectives, the costs of adversarial right of entry and compensation proceedings and damaged relationships with landowners). Furthermore, the arbitration cost provision implicitly recognizes that companies make offers to owners that exceed the compensation owners are entitled to under the $N E B A C t$ and encourages them to do so; 115

The modified NOVA annual payments program put forward by the owners produced compensation having a present value ranging between eight and 40 times the per acre value of the titled unit in which the rights-of-way were located (in some instances the compensation requested for the right-of-way amounted to more than the value of the entire titled unit). The NOVA program was an anomaly and had not been followed by industry, surface rights tribunals or the courts;

The Alberta right-of-entry fee equivalent that Alliance paid in respect of its easement agreements cannot be construed as a component of a "pattern of dealings," let alone "the market value of lands taken," and is not required to be paid under the NEB Act. Indeed, even under the Alberta Surface Rights $A c t$, it is clearly defined as constituting an amount supplemental to any compensation to be paid. ${ }^{116}$ Therefore, it should not be included in any compensation award under the $N E B A c t$;

The determination of compensation for the acquisition of rights-of-way under the $N E B$ Act involves, having regard to s. 98, a two-step process pursuant to which the compensation must first be determined as a lump sum amount, followed by an election on the part of the landowner as to how the payment of that compensation should be structured (that is, either as a lump sum or by instalments over time). In any event, the present value of the compensation should not be substantially changed merely as a result of the election of the owner. The principal purpose of the election, having regard to s. 97(1)(b), is to enable owners to have their land acquisition compensation awards reviewed for possible changes in land value. The approach proposed by the owners, based on a modified NOVA program, constituted an improper election as it did not result in a present value equivalent to the appropriate compensation for the acquisition as a lump sum. Instead, it amounted to an election to receive that compensation again and again; and

$N E B$ ACl, supra note 4, s. 99. Section 99 establishes an owner's entillement to compensation for reasonabiy incurred costs at a threshold of 85 percent of the company's offer for compensation. Owners are never at risk of having to pay the company's costs, regardless of the success of their claims, though they may be responsible for their own reasonably incurred costs should a pipeline arbitration committee's award be less than 85 pereent of what the company offered. 'This section is presumably intended to foster settlements of claims by encouraging pipeline companies to make generous offers and by creating a risk to owners for their own costs if they do not accept such offers. 
There should be no compensation awarded for the "controlled area" because there is no evidence that it will injuriously affect the remaining agricultural lands of the owners (see Part V.A). Where the highest and best use of the subject lands is other than agricultural (such as commercial, residential, industrial or transitional), injurious affection at the present time must be proven by the owners.

The Pipeline Arbitration Committee's findings with regard to compensation for land acquisition were generally as follows:

The determination of compensation for the acquisition of lands under the $N E B A C t$ requires an assessment of the "market value of the lands taken" and does not allow for a "global award" (consideration of other factors such as ongoing adverse effects, etc.) as suggested by the owners;

Small country residential parcels are not comparable to pipeline easements. Where there is a pattern of compensation established for the voluntary acquisition of pipeline easements, that pattern constitutes a reliable small-parcel comparable for establishing a "market value for the lands taken" under the $N E B A C t$. Where no such pattern is discernible, the default approach is to assess the market value of the rightof-way on the basis of the per acre market value of the titled unit. In either instance, the per acre compensation for the temporary work space is half of that determined in respect of the permanent easement;

The Alberta entry fee of $\$ 500$ per acre does not constitute an element of the "market value of the lands taken" under the $N E B A C t$, nor can it be considered as an "other factor" in determining compensation for land acquisition;

- There is no support for the proposition of the owners that the NOVA annual payment program constitutes a "pattern of dealings," and in any event, particularly as modified by the owners, it results in inflated compensation for the acquisition of lands;

The NEB Act does not permit the Pipeline Arbitration Committee to impose any form of a land rental. Instead, it must determine land acquisition compensation as a lump sum, followed by an election by the owner to receive that compensation as a lump sum, or by periodic or annual payments of equal or different amounts over a period of time; ${ }^{17}$

There was no evidence presented showing that the "controlled area" diminishes the value of the remaining lands of the owners or has in fact impacted on the owners" uses of their lands. Accordingly, no compensation in respect of the "controlled area" was awarded; and 
There was no evidence that the Alliance Pipeline injuriously affected the remaining agricultural lands of the owners. ${ }^{118}$

\section{ANALYSIS AND COMMENTS}

The effect of the decisions was in all cases to award the owners who advanced compensation claims less than they and their neighbours were offered by Alliance to enter into easement agreements, but, in some instances, more than Alliance argued they were entitled to under the NEB Act. However, unlike Alliance's settlement offers, which were strictly in the form of lump sums, the owners were entitled to make an election as to how the payment of the compensation was to be made. In that regard, the Pipeline Arbitration Committee's decisions suggested that annual or periodic payments, if selected, could be structured in a myriad of ways, but should be construed as instalments rather than rental payments.

The Pipeline Arbitration Committee has effectively adopted the approaches followed primarily in Alberta for determining compensation for right-of-way acquisitions under the Surface Rights $A c t$, though on the basis of different reasoning. The decisions effectively support "pattern of dealings" evidence, despite its weaknesses and its limited applicability having regard to the national scope of the $N E B A c t$, as the preferred basis upon which to determine pipeline right-of-way compensation. The conventional methodology based on expropriation principles, which can be universally applied in the national context, is established as the alternate approach. ${ }^{119}$

There is no doubt that the $N E B A C l$ provides for pipeline right-of-way acquisition compensation to be paid as a lump sum or by annual or periodic payments. However, it stands to reason that an owner should not realize a windfall merely by virtue of an election to receive an award of compensation over time as opposed to a lump sum. The primary purpose for the provision of an election as to the method of compensation payment was the perceived need to allow for a review of that compensation should there be a change in the market value of the lands acquired over some period of time. ${ }^{120}$ By structuring compensation

In the one case involving lands near Edson, Alberta, which were in transition from agricultural to highway commercial use, the Pipeline Arbitration Committee aceepted Alliance's argument that there was evidence, though somewhat speculative, of injurious affection of the remaining lands of the owner. In that instance. the Pipeline Arbitration Committee made a relatively modest award of compensation for injurious affection to be paid by Alliance only if the owner elected to receive the compensation for the right-of-way taking as a lump sum. If the owner elected to receive the compensation by annual or periodic payments, the issue of injurious affection was to be deferred for later consideration during a future five-year review.

The $N E B A C t$ is applicable to federal pipelines in many areas of Canada. Consequently, any methodology for determining compensation for the acquisition of rights-of-way under the $N E B A C t$ should be workable in any area of Canada. Only the mellodology based upon fundamentally sound expropriation principles is capable of universal application. For instance, it is equally applicable in Cape Breton. Nova Scotia, where presumably there would be no "pattern of dealings" cvidence available, as it is in Alberta, which is home to many pipelines.

1:" It is not apparent how such payments would be adjusted for changes in the market value of the lands having regard to the time value of noncy. Amounts paid prior to a review would presumably have to be adjusted. as would amounts still outstanding having regard to changed circumstances. In the end, the need for a review for changes in land value appears to ignore that money paid at the time of the taking could be invested. including in other lands or to pay down a mortgage, in such a manner that 
payments over a period of time, owners who elect periodic payments avoid the perceived risk that the compensation awarded for the acquisition of lands based on the value of their lands at the time of the taking is frozen in time. Other owners who do not anticipate significant changes in land values (or for many other reasons) may prefer to receive the compensation award as a lump sum. In either case, the award of compensation determined at the time of the taking should presumably have the same present value.

The decisions of the Pipeline Arbitration Committee have, predictably, been appealed by the owners to the Federal Court. ${ }^{121}$ Alliance has cross-appealed those compensation awards based on "pattern of dealings" evidence.

While numerous grounds for appeal have been cited, the fundamental issues will be whether the Pipeline Arbitration Committee's approach for determining the market value of lands taken, which it stated was based on the Cochin and Patson cases, is correct; and whether periodic or annual payments, if selected by an owner, are intended to be in the form of a structured payment of a determinate sum of compensation by instalments over time, or rather a land rent.

Notwithstanding the comments of the Minister of Natural Resources in the House of Commons during the second reading of the $N E B A c t$ amending legislation to the effect that it would provide an owner the option of receiving periodic payments "in the nature of a land rental," ${ }^{122}$ the wording of the legislation itself, both in English and in French, ${ }^{123}$ as well as the underlying principle of compensation, all point to structured payments of compensation and not rent, which implies a refurn on property.

would likely keep approximate pace with appreciating land values. However, 10 the extent that some injurious affect of the pipeline is not appreciated at the time of the taking. then the provision for a review may allow for that matter to be revisited having regard to changed circumstances (such as urban expansion or increased rural tesidential development).

$131 \quad N E B$ ICt, supra note 4 , s. 101.

13: House of Commons Debates. supra note 17 at 8006 . The Minister's comments do not meet the requirements for use as difect evidence of the meaning of s. $98(1)$ of the NEB. Act, ibid. At best, the Minister's comments can be alluded to for indirect evidence of the purpose of the legislation. With respect to the use of extrinsic aids of interpretation, sec the discussion of the exclusionary rule in: Letang v. Cooper, [1964] 2 All E.R. 929 at 933 (C.A.); Pepper (Inspector of Taxes) v. Ilart. [1993] I All E.R. 42 at 69 (H.L.); Laidlaw v. Metropolitan Toronto (Miumicipality of). [1978] 2 S.C.R. 736. In this instance, the problem that was intended to be addressed was the perceived unfaimess that might result from the one-lime determination of compensation for land acquisition where there was potential for future changes in land values.

121 The shared meaning rule requires that bilingual legislation be taken into accoum in both language versions and the same meaning assigned to both. The noun "versements" used in the French version of s. 98(1) of the $N E B$ ACt, ibid. means instalment. The use of the Ierm "versements piriodiques," like the English term "periodic payments," suggests the paynient of a finite sum by regular instalments. particularly when read in conjunction with the phrase "over a period of time" or, as stated in lluc French version, "une pertiode donnee" (a given period). Had Parliament intended awards of compensation in the form of annual rentals. it presumably would not have chosen the wording of $s .98(1)$. which requires an initial determination of compensation as a lump sum, and it could have made explicit relerence to "rent" or "rental payments," terms which do not appear in either the French or the English version of the NEB Act. 


\section{B. AlbERTA: SURFACE RIGHTS ACT}

The Surface Rights Act explicitly contemplates the payment of compensation on an annual or periodic basis. However, such compensation is, strictly speaking, to be awarded for ongoing damages, and not in connection with the acquisition of an interest in land. Accordingly, the policy in Alberta has been to award only lump sum compensation for the acquisition of pipeline rights-of-way based on the general rule that the surface disturbance caused by buried pipelines, in contrast to above ground facilities, is short-lived. Buried pipelines, particularly across agricultural lands, have typically not been viewed as causing any long-term loss of use of the right-of-way area or ongoing adverse effects to the adjacent lands. However, a group of owners in Alberta recently challenged this commonly held view, asserting before the SRB and, on appeal to the Court of Queen's Bench, that their uniquely situated lands should attract annual compensation.

\section{Corridor Pipeline LAND ACQUisition Program}

The Zubick case involved the construction by Corridor Pipeline Ltd. ${ }^{124}$ (Corridor) of $493 \mathrm{~km}$ parallel pipelines from the Shell Muskeg River Mine in the Athabasca Tar Sands near Fort McMurray to an upgrader near Scotford, ${ }^{125}$ and on to marketing terminals near Edmonton. ${ }^{126}$ Many of the lands traversed by the pipeline had two or more pipelines, and a communications transmission line, running across them before they were approached by Corridor. As part of its largely successful negotiations of right-of-way acquisitions with individual owners, Corridor was alleged to have committed to top up the agreed lump sum payment amount if, in its dealings with other owners of similarly situated properties, it agreed, or was required, to pay a higher amount. In no circumstances did Corridor offer or agree to pay annual payments for pipeline rights-of-way. A number of owners did not accept Corridor's lump sum offers, requiring Corridor to obtain rights of entry under the Surface Rights Act. ${ }^{127}$ The owners pursued their demands for, among other things, annual payments before the SRB. ${ }^{128}$

\section{Relevant SURFACE RJGHTS ACt Provisions}

The factors that the SRB may consider in determining compensation under the Surface Rights $A c t$ are, in relevant part, as follows:

25(1) The Board, in determining the amount of compensation payable, may consider

Supra note 3. Corridor Pipeline Ltd. is a wholly owned subsidiary of BC Gas inc., now named Terasen lnc.

A 24 in (610 mm) diameter diluled bitumen line and a 12 in (323.9 mm) diameter condensate return line.

A 20 in (508 $\mathrm{mm}$ ) diameter synthetic crude oil line and a 16 in (406 $\mathrm{mm}$ ) diameter supplementary feedstock return line.

Supra note 2, ss. 12, 15; Surface Rights Act General Regutation, Alta. Reg. 189/2001; and Surface Rights Act Rules of Procedure and Practice, Alta. Reg. 190/2001.

Surface Rights Act, ibid., s. 23. Pursuant to ss. 19 and 20 respectively, a pipeline operator is required to pay the mandated $\$ 500$-per-acre entry fee as well as 80 percent of its last written offer of compensation to the owner prior to exercising its right of entry. 
(a) the amount the land granted to the operator might be expecied to realize if sold in the open market by a willing seller to a willing buyer on the date the right of entry order was made,

(b) the per acre value, on the date the right of entry order was made, of the tilled unit in which the land granted to the operator is located, based on the highest approved use of the land,

(c) the loss of use by the owner or occupant of the area granted to the operator,

(d) the adverse effect of the area granted to the operator on the remaining land of the owner or occupant and the misance, inconvenience and noise that might be caused by or arise from or in connection with the operations of the operator,

(e) the damage to the land in the aren granted to the operator that might be caused by the operations of the operator, and

(f) any other factors that the Board considers proper under the circumstances. ${ }^{129}$

Strictly speaking, only those factors set out in ss. $25(1)$ (a), (b) and (d) are relevant to right-ofway acquisition to the extent that they relate to the value of the lands acquired and any injurious affection of the remaining lands of the owner. ${ }^{130}$ The remaining considerations, including the "nuisance, inconvenience and noise" referenced in s. 25(1)(d), really relate to damages from the operations of the pipeline company. They are cited here only because the owners' claims against Corridor included annual payments that, while explicitly contemplated under the Surface Rights $A c t$, are specifically in relation to ongoing disturbance damages such as loss of use and adverse effect (more precisely nuisance and inconvenience):

$27(1)$ (d) "rate of compensation" means the amount of compensation payable on an annual or other periodic basis under a surface lease or compensation order in respect of the matters referred to in section $25(1)(c)$ and (d).

\section{SURFACE Rights BoARD AND AlBERTA COURT OF QUEEN'S BENCH DECISIONS}

The owners in Zubick ${ }^{131}$ argued that Corridor's pipelines, in conjunction with existing linear developments and the prospect for additional paralleling rights-of-way, established a de facto corridor through their properties which would uniquely restrict the future use of those lands. Accordingly, the owners asserted that the determination of compensation for the taking of the right-of-way interests by Corridor should not be restricted to a valuation exercise under ss. 25(1)(a) and (b) of the Surface Rights $A c t$, but should also take into consideration the suggested long-term impacts captured by the other factors listed under $\mathbf{S}$. 25(1).

The SRB agreed that, in the circumstances, Corridor's pipelines would have more longterm impact on the future use of the subject lands than might be typical for most pipelines. Though the SRB found the owners' case to be compelling, it did not see fit to award annual compensation. In refusing to award annual compensation, the SRB indicated that it was mindful of the potential inequitable treatment of Corridor relative to the operators of existing

124 Ibid. [emphasis added].

150 Ibid., S. 25(2) permits the SRB to ignore the residual and reversionary value to the owner of the land granted.

171 Supra note 3 (the SRB Decisions provide a list of owners). 
pipelines (who would have paid lump sum compensation) in the de facto corridor, ${ }^{132}$ as well as other unintended consequences. Nevertheless, the SRB accepted that the situation was sufficiently unique ${ }^{133}$ to depart from its normal practice of determining compensation based on a "pattern of dealings"134 or, if no pattern is found to exist, the per acre value of the titled unit in which the right-of-way is located. Instead, the SRB relied on its own general knowledge of compensation paid in other areas of the province to arrive at a higher lump sum rate of compensation than suggested by either normally accepted approach. ${ }^{133}$

Both the owners and Corridor appealed the decision to the Alberta Court of Queen's Bench. ${ }^{136}$ The Court upheld the SRB's decision, although it curiously awarded lump-sum compensation at an arbitrarily higher rate than had the SRB. Justice Sanderman found that the evidence supported the existence of a de facto corridor and decided that such circumstances called for a one-time premium payment of compensation relative to the amount that might normally be expected. He inferred from the SRB's apparent rejection of the traditional valuation approaches suggested by ss. 25(I)(a) and (b) of the Surface Rights Act that the SRB placed greater emphasis on the remaining enumerated factors of loss of use of the right-of-way area acquired, the adverse effect and damage to the remaining lands of the owner, and "any other factors that the [SRB] considers proper under the circumstances." Justice Sanderman summarized his reasoning as follows:

In the end result, annual compensation was not justified in this case. The unique situation that the owners find themselves in calls for a premium payment for the taking of the right to build a pipeline. They deserve more than they normally would receive based upon an application of the first two factors of $s$. $25(1)$. This situation calls for a broader interpretation of this section. The other subsections are called into play. The premium

11: The owners contended that the establishment of multiple pipelines between important receipt and delivery points effectively changed the highest and best use of the lands to an industrial corridor. Such a proposition, however, runs counter to the principle that the highest and best use of the lands is to be assessed without considering the scheme for which they are acquired. Support for this proposition is found in the Surface Rights Act, supra note 2, s. 25(1)(b) that requires the highest approved use of the lands to be considered, which may not necessarily correspond to its highest and best use.

13. The owners listed a host of speculative and contingent polential damages that might arise from a pipeline right-of-way in the long term and suggested that such damages could effectively be addressed through annual payments determined at the time of the taking. It is not clear how such compensation, should such speculative damages not actually arise, would be paid back to the company. Nor is it clear how a compensation award based on speculative damages is warranted when provisions, such as $s .30$ of the Surface Rights $A c t$, ibid. permit separate claims for damages from operations as they occur.

ii - Corridor presented evidence of a "pattern of dealings" based on the agreements it was able to negotiate with other owners in the area, as well as those of other operators. The SRB appears to have rejected this evidence based on a finding of fact (whether correct or not) that Corridor had committed to "top-up" compensation paid to owners for right-of-way agreements if they agreed or were required to pay greater compensation to other owners. The SRB held that such an arrangement precluded the consideration of Corridor's own agreements in establishing a "paltern of dealings."

in Expropriation tribunals are sometimes asked to give weight to prior awards of the tribunal. it seems trite to say, however, that the decision in each case should be decided on the evidence that is submitted in that case. Arguably, the parties in this instance had no opportunity to test the evidence being relied upon by the SRB in making its decision.

14. Surface Rights $A c l$, supra note 2, s. 26(6) provides that "[a]n appeal to the Court shall be in the form of a new hearing." Nevertheless, deference is still accorded to SRB decisions: see Caswell $v$. Alexandra Petroleum Ltd., [1972] 3 W.W.R. 700 at 728 (Alta. S.C.(A.D.)); Lamb v. Canadian Resources Oil and Cias l.dd. [1976] 4 W W.R 79 at 87 (S.C.C.). 
payment to which the owners are entilled is $\$ 1,200$ per acre for the right of way. This is an increase of $\$ 200$ per acre [over the SRB's award]. ${ }^{1.7}$

The Court's refusal to award annual payments should not be construed as an outright prohibition of such compensation. In this particular instance, the annual compensation proposed by the landowners (based as in the case of Alliance on a variation of the formula implemented by NOVA in the early 1980s) was rejected by the Court as unscientific, illogical and unfair on the grounds that it would, over the life of the pipeline, result in each owner being paid many times the amount that would be required to buy the subject property outright using the accepted expropriation valuation method. ${ }^{138}$ Presumably, annual compensation that did not produce such a windfall might have been acceptable to the Court, though it is then doubtful that an owner would have incentive for requesting it.

\section{ANAL.YSIS AND COMMENTS}

Zubick is perhaps more notable for the questions that it leaves unanswered than it is for the issues that it resolves. It holds that neither "pattern of dealings" evidence, nor the default consideration of the per acre market value of the titled unit, is appropriate when dealing with a de facto corridor. ${ }^{139}$ However, the decision does not provide a principled alternative approach for determining what constitutes appropriate compensation in the circumstances, and calls instead for arbitrarily inflated awards.

In the final analysis, Zubick exemplifies how those charged with the determination of surface rights compensation in Alberta have often disregarded the principles underlying expropriation law. It is not at all apparent how lands that are held to have a long-term agricultural highest and best use, which would suggest no injurious affection of lands outside the right-of-way, might necessitate some arbitrary premium. If indeed there was an injurious affection, its present value would presumably be quantifiable based on evidence in the same way it is in expropriation cases involving partial takings.

\section{INJURIOUS AFFECTION}

Owners of lands traversed by pipelines may claim compensation not only for the right-ofway acquired by the pipeline company, but also for the adverse effects of that taking on the remainder of their lands. Such claims are typically based on an alleged interference with an owner's property rights outside of the right-of-way, whether in relation to the current or highest and best use of the lands. Particularly in the context of agricultural lands, the alleged restrictions on land use as a result of pipelines have not typically been reflected in the perceptions of the marketplace. ${ }^{140}$ Nevertheless, owners have in a number of recent cases advanced claims for injurious affection founded largely on speculative restrictions on land use.

The author is not aware of any studies that indicate pipelines, particularly those transmitting sweet natural gas or low vapour pressure crude oil or products, have a statistically measurable negative influence on property values. 


\section{A. FEderal: NEB ACr SECtion 112 "CONTROLlLed AREA"}

As of 1990, the regulation of excavation activities in proximity to NEB-regulated pipeline has been extended beyond the limits of the pipeline right-of-way. ${ }^{141}$ Section $112(1)$ of the $N E B A C t$ provides as follows:

Subject to subsection (5), no person shall. umless leave is first obtained from the Board, construct a facility across, on, along or under a pipelinc or excovate using power-operated equipment or explosives within thirty mesres of a pipeline. ${ }^{142}$

In light of the broad definition of "pipeline" in s. 2 of the $N E B A C t$, which includes any real property connected therewith, the $30 \mathrm{~m}$ in s. 112 is read as being measured from each edge of a federally regulated right-of-way, as opposed to from the centre line of the pipe itself.

Section 112(1) must be read in conjunction with the regulations made by the NEB pursuant to its authority under $5.112(5) .{ }^{143}$ Those regulations, namely the National Energy Board Pipeline Crossing Regulations, Part $I^{144}$ and Part $2,{ }^{145}$ detail the circumstances in which leave of the NEB under s. $112(1)$ is not required and the responsibilities of persons and pipeline companies when certain ground disturbances are proposed to be undertaken in relative proximity to a pipeline. ${ }^{146}$ The result is by no means a prohibition of such excavations. Rather, the intention behind the regulatory requirement is the protection of the public and the environment by ensuring that persons undertaking excavations in proximity to pipelines appropriately mitigate any attendant risks. ${ }^{147}$

\section{l. Al.l.IANCE Pipfl.ine}

Several owners who served notices of arbitration to the Minister under the NEB ACt claimed, among other things, compensation in connection with the 30-m-wide "controlled area" to each side of Alliance's pipeline. At the outset, the compensation requested was the same as that claimed for the acquisition of the rights-of-way themselves. ${ }^{148}$ However, over the long process involved in getting the appointed pipeline arbitration committees to consider compensation for the "controlled area," the owners abandoned the argument that the

An Act to Amend the Nutional Energy Board Act and to Repeal Certain Enactments in Consequence Thereof. S.C. 1990 , c. 7. s. 28.

is: Supra note 4 [emphasis added].

is Ibid., s. I $12(5)$ (which provides that the NEB may make regulations governing, among other things, excavations within $30 \mathrm{~m}$ of a pipeline and the circumstances in which or conditions under which leave of the NEB under $s .112$ is not required).

11 S.O.R. $11988-528$.

its S.O.R./1988-529.

18. For example, the requirements do not apply to activities that disturb less than $30 \mathrm{~cm}$ of ground betow the initial grade and do not reduce the cover over the pipe. Accordingly. normal farming activities are not captured.

The NEB has stated that the purpose of the "controlled area" is public safety and environmental protection, and that it is not part of the right-of-way in which the pipelinc company has any interest. See e.g. Reasons for Decision in the Matter of Trans Quebec \& Maritimes Pipeline Inc. PNGTS Extension April 1998), GH -1-97 at 32 (NEB). 
"controlled area" constituted a de facto taking and reframed their claims in terms of injurious affection.

\section{a. Minister of Natural Resources' Decision}

The Minister, pursuant to his discretion under s. 9l(2) of the $N E B A C t$, requested written submissions from the owners and Alliance concerning whether certain matters raised in the notices of arbitration, including the "controlled area," were within the scope of matters to which the negotiation and arbitration provisions of the $N E B A C l$ applied. Having considered those submissions, the Minister appointed pipeline arbitration committees and referred the owners' notices of arbitration to them, subject to the restriction that they would be prohibited from considering compensation for the "controlled area."

\section{b. Federal Court Judicial Review}

In anticipation of the Minister's appointment of pipeline arbitration committees subject to restricted terms of reference, the owners filed an application for judicial review of the Minister's decision in the Federal Court. ${ }^{149}$ Notwithstanding certain irregularities in the commencement of the application, the Court allowed the application to proceed. In the meantime, the arbitrations proceeded in 2001 and 2002 , subject to the strictures imposed by the Minister.

Justice Tremblay-Lamer held that the NEB Act s. 84(a) ${ }^{150}$ requirement that matters referred for arbitration be "directly related to the activities of the company" precluded the referral of a compensation claim for the "controlled area" to such proceedings. She reasoned that the "controlled area" was a requirement of Parliament in the interests of public safety and the environment that did not "require the immediate participation of the pipeline company," and was therefore not "directly related to" the activities of acquisition of lands for, or construction and maintenance of, a pipeline as required by the $N E B$ Act. ${ }^{\mid s !}$

The owners successfully appealed the decision to the Federal Court of Appeal, ${ }^{152}$ which directed the Minister to refer the matter of compensation for the "controlled area" to arbitration. As in the Trial Division, the Federal Court of Appeal's decision turned on the interpretation of s. 84 of the $N E B$ Act defining the scope of compensation matters to which the NEB Act arbitration provisions apply. The Federal Court of Appeal held that the exclusion under 5.84 should be read more narrowly than the Minister or the judicial review judge did. The Court reasoned that the "controlled area" did not arise, whether directly or indirectly, from any of the listed activities of the company, but rather from the mere existence of the pipeline. Accordingly, it did not come within the ambit of any of the exceptional provisions of s. 84, and an arbitration committee could, therefore, properly award 
compensation for the "controlled area," not as a taking, but for injurious affection if appraisal or other evidence demonstrated a diminution in the value of the affected lands. ${ }^{153}$

Alliance filed an application for leave to appeal to the Supreme Court of Canada in April 2003. Four other major NEB regulated pipeline companies provided support for Alliance's leave application by swearing affidavits regarding the national scope and implications of the Federal Court of Appeal's interpretation of the NEB Act. ${ }^{154}$ Nevertheless, the Court refused Alliance's application for leave to appeal the Federal Court of Appeal's decision. ${ }^{135}$ The Court, as is usual in such matters, did not give reasons for denying leave. The Federal Court of Appeal's decision, therefore, constitutes the final word on the matter.

\section{c. Pipeline Arbitration Committee Decisions}

It should be noted that Alliance did not seek to stay the Federal Court of Appeal's decision pending the Supreme Court of Canada's consideration of Alliance's leave application. As the pipeline arbitration committees appointed by the Minister to consider the landowners' claims for compensation had yet to render their decisions, Alliance requested that the matter of the "controlled area" be referred to the same committees that had heard the remainder of the owners' claims in $200 \mathrm{I}$ and 2002. The Minister granted Alliance's request, and the pipeline arbitration committees agreed to hold their decisions in abeyance to allow the parties to present evidence and submissions on the "controlled area." However, the owners did not avail themselves of the opportunity to present additional evidence to either committee. ${ }^{156}$ In September 2003, the first of the pipeline arbitration committees seized of compensation claims against Alliance rendered its decisions, awarding no compensation in respect of the "controlled area" in the absence of any evidence on the matter. ${ }^{157}$

\section{ANALYSIS AND COMMENTS}

While the pipeline arbitration committees appointed in relation to Alliance have, to date, not awarded any compensation for the "controlled area," they did so on the basis that no probative evidence of injurious affection of any kind was presented in those cases.

The Court focused on what it presumed to be the particular emphasis on claims arising from certain types of "activities" in clausc 84(a) (the exclusion of "claims against a company arising from the activities of the company unless those activities are directly related") as opposed to claims generally (for instance, it could have simply excluded "claims against a company unless those claims are directly
related").

See supra note 5 discussion regarding class action by owners seeking compensation for the alleged impacts of the "controlled area" against TransCanada Pipelines Limited and Enbridge Pipelines Inc., and recently released Federal Court's decision in Maritimes \& Northeast, supra note 7. [2003] S.C.C.A. No. 193

19. The owners chose instead to simply make additional submissions through counsel to the effect that the Pipeline Arbitration Committce should award annual compensation as requested to account for the intangible impacts of the "controlled area." Facing no evidence on the matter, Alliance chose not to present any evidence of its own and submitted that the Pipeline Arbitration Committee should not award compensation for injurious affection wilhout evidence. 
The fact remains that the "controlled area" requirements do not actually constitute a prohibition against development. Rather, they stem from a recognition that one of the leading causes of pipeline failures in Canada is third party contact, and establish a process for ensuring ground disturbances near pipelines are undertaken in a safe manner. If regulators were confident that a pipeline company's right-of-way rights would always be respected, ${ }^{158}$ there would presumably not even be a perceived need for a "controlled area."

It seems highly unlikely that the facts in a particular case would ever support an award for injurious affection arising from the "controlled area." Nevertheless, it remains that such claims can still be advanced and that a particular arbitration committee might be inclined to recognize any perceived limitations on owners' use of their lands. ${ }^{159}$

\section{B. Alberta: De Facto Pipeline Corridor}

In Zubick, Sanderman J. of the Alberta Court of Queen's Bench determined that the existence of a de facto corridor called for premium compensation to be paid for pipeline rights-of-way relative to the situation where no de facto corridor exists. ${ }^{180}$ In so doing, he did not explicitly attribute the premium to a particular factor under s. 25(1) of the Surface Rights $A c t$, but to one or more factors including adverse effect. Having regard to the recognition of a special impact on lands upon which a de facto corridor has been imposed, the implication is that it somehow injuriously affects the remaining lands of an owner. ${ }^{161}$

\section{CORRIDOR PIPELINE}

The landowners who sought compensation under the Surface Rights $A c t$ for the acquisition by Corridor ${ }^{162}$ of rights-of-way did not make claims for injurious affection per se. Rather, they proposed premium compensation and annual payments based on valuations that assumed the de facto corridor had changed the highest and best use of their lands to an industrial corridor, as well as various speculative ongoing disturbance damages. However, the underlying premise for the landowners' unconventional claims was that the existence of the de facto corridor precluded any other use of their lands than agricultural in the long term. Given that a reasonably prospective higher and better use would be expected to be reflected

Aside from the requirement to go through an administrative process before undertaking a ground disturbance, the "controlled area" arguably does not impose any more of a restriction on an owner's use of his or her lands outside of a pipeline right-of-way than does the right-of-way itself. See Alliance Pipeline Ltd. v. Seibert (2003), 342 A.R. 343 (Q.B.), and B.C. Gas Utility Lid. v. Alpha Manufacturing Inc., [1998] B.C.J. No. 939 (S.C.) (QL).

The "restriction" imposed on an owner's use of his or her lands by the "controlled area" is, in most conceivable circumstances, not more than a brief administrative delay. To the extent that it does cause an inconvenience, the NEB is currently reviewing the processes for regulating ground disturbances under National Energy Board Pipeline Crossing Regulations, Parts I \& 2, supra notes 144 and 145, governing activities within the "controlled area," with a view to replacing them with a more streamined process under the draft Damage Prevention Regulations. The NEB is still seeking input on the draft regulations at this point.

Supra note 3. If not injurious affection, the implication is of undefined or speculative damages, which presumably would not be compensable: NOVA v. Will Farms Lid. (1981), 31 A.R. 378 (C.A.).

Zubick, supra note 3.

See supra note 124. 
in the market value of the subject lands, it is not clear why the landowners' claims were not framed in terms of injurious affection to their remaining lands.

\section{a. Alberta Court of Queen's Bench Decision}

It is not readily apparent what constitutes a de facto corridor. Indeed, Sanderman J.'s determination that, on the facts in Zubick, a de facto corridor had been established on the appellants' lands appears to be without precedent.

The unique finding of a de facto corridor appears to have been greatly influenced by evidence of the Government of Alberta's early 1970 s plan, which never came to fruition. The plan sought to establish a corridor to transport natural resources from the Fort McMurray region of Alberta to the industrial heartland northeast of Edmonton for processing. Although the so-called Athabasca Tar Sands Corridor never came into existence as a result of the exercise of authority by the provincial government (that is, through the use of restrictive zoning, public acquisition of the lands or creation of a corridor authority), a number of pipelines and a communication transmission line were ultimately constructed between the points the corridor was intended to connect. ${ }^{163}$ In the result, certain landowners had paralleling pipelines installed on their lands and, having regard to the strategic location of their lands and the encouragement of pipeline operators by regulators to follow existing linear disturbances, faced a realistic prospect of additional pipelines being situated on their properties.

Nevertheless, Sanderman J. also concluded that the evidence overwheimingly established that the highest and best use of the lands had been, remained and would be for agricultural purposes. Accordingly, Sanderman J. rejected the landowners' contention, and the valuation based thereon, that the highest and best use of the lands would be as an energy corridor. ${ }^{104}$

Notwithstanding the finding that the subject lands would remain in agricultural use in the long term, Sanderman J. concluded that the existence of a de facto corridor called for a onetime premium payment of compensation. ${ }^{165}$ The premium, arbitrarily determined, was attributed without any specificity to the Surface Rights Act s. 25(1) enumerated factors of land use loss, the adverse effect and damage to the remaining lands of the owner, and "any other factors that the [SRB] considers proper under the circumstances."

\section{ANALYSIS AND COMMENTS}

The conclusion in Zubick that the highest and best use of the subject lands was and would remain agricultural is difficult to reconcile with the arbitrary awarding of premium compensation on the basis of loss of use, injurious affection or some other undefined factor. It is not apparent how there is any greater or more demonstrable loss of use or adverse effect for the first, second or third pipeline in a de facto corridor, particularly in circumstances

Though apparently not in evidence, the rights-of-way associated with various pipelines between the Fort McMurray region and the industrial area northeast of Edmonton did not all follow the same precise
route.

li.t Zubick. supra note 3 at paras. 53-54.

lis. $\quad$ lbid. at para. 62. 
where no injurious affection is usually found and the reversionary value of the pipeline rightof-way to the owner is customarily ignored. Nor is it apparent why, if there is in fact such loss of use or injurious affection, it should not have to be reasonably quantified on the basis of the evidence.

Zubick does not define the considerations, such as a threshold number of parallel pipelines, that determine whether a de facto corridor exists, and, if so, what its boundaries are. Other than the defunct provincial government plan to establish a corridor (the precise route and extent of which is unknown) across or in proximity to their lands, the circumstances in which the landowners in Zubick found themselves are arguably not unique relative to many other owners of lands in Alberta (or elsewhere) that are traversed by multiple pipelines. It is therefore unclear what other circumstances might give rise to a finding of a de facto corridor, and whether, in and of itself, that determination should have any implication with respect to compensation.

The so-called de facto corridor in Zubick lacks many of the hallmarks of a transportation or utility corridor. A corridor is a type of highest and best use, is not typically subject to arbitrary delineation and, to be marketable as a corridor, must be in the control of a single entity (thus allowing a user to avoid buying right-of-way from many different owners). ${ }^{160}$ Without singularity of ownership and control of usage of a physical corridor, there is no merchantable right-of-way corridor that might warrant premium compensation relative to other adjacent land uses in recognition of the savings of time and expense to the user.

The areas in Alberta that are reserved for use as transportation or utility corridors are creatures of statute. For instance, certain lands are preserved by the Government of Alberta for use as a transportation or utility corridor by designating them as restricted development areas under Schedule $S$ of Alberta's Government Organization Act ${ }^{167}$ It is notable that, in the acquisition of rights-of-way within a transportation and utility corridor, no consideration is to be given to the artificial depreciation or appreciation as a result of the rezoning of lands resulting from the creation of a restricted development area. The Alberta Court of Appeal in TransAlta Utilities Corp. v. MacTaggart ${ }^{168}$ held that s. 45(e) of the Expropriation Act ${ }^{169}$ properly reflected the common law valuation principle to be applied equally to the lands taken or injuriously affected:

45 In determining the value of the land. no account may be laken ol'

Albert N. Allen. "The Appraisal of Easements" Right of Way Magazine (November/December 200I) 41.

R.S.A. 2000. C. G-10.

(1989), 101 A.R. 286 at $288-89$ (C.A.), leave to appeal refused. 109 A.R. 320 (note) (S.C.C.). Section 45(e) of the Expropriation Ict, R.S.A. 1980, c. E-16, was held to be a codification of the principle enunciated in Mckee v. Province of Alberta (1967), 16 L.C.R. 35 (Alta. S.C.(T.D.)). The lands in question were along a ravine area now in the City of Edmonton and within a restricted development area (RDA) for a Iransportation utility corridor. The utility company was required to locate its transmission line taking within the cotridor and, in doing so, isolated an area from the rest of the parcel. Though the lands were in agricultural use (a secondary use not incompatible with the restriction on land use). the evidence indicated that, but for the RDA, they would be used for high class residential development. The lands taken. as well as the lands injuriously affected, were valued accordingly, recognizing some residual value for the limited uses.

R.S.A. 1980, c. E-16, now R.S.A. 2000, c. E-13. 
(e) any increase or decrease in value that results from the imposition or amendment of a land use bylaw, land use classification or analogous enactment made with a view to the development under which the land is expropriated.

Accordingly, the proper valuation principle to be applied to lands within an established transportation and utility corridor in Alberta is to ignore the effect of the land use classification.

Whether Zubick will be followed in other surface rights cases remains to be seen. If so, its effect would be to introduce further and unnecessary (having regard to well-established expropriation compensation principles) arbitrariness to the determination of surface rights compensation awards. It might also serve to discourage pipeline proponents from following existing linear disturbances when selecting pipeline routes.

\section{Surface Rigits Compensation Practice Considerations}

The adjudication of surface rights compensation is generally delegated to administrative tribunals established with a view to resolve claims efficiently and expeditiously. To that end, surface rights compensation tribunal proceedings are often characterized by their relative informality. Tribunals such as the SRB are, for example, typically not bound by the rules of evidence and often do not require advance disclosure of the case to be met. ${ }^{170}$ While laudable in terms of the desire to facilitate the assertion of claims for compensation by individual owners, relatively informal surface rights proceedings may come at the expense of natural justice and procedural fairness and, consequently, the respective parties in terms of the awards of compensation.

\section{A. Surface Rights Board Practice.}

The SRB does not have any published set of rules governing its compensation proceedings. The Surface Rights Rules of Procedure and Practice ${ }^{171}$ are concemed primarily with right of entry proceedings. While the SRB ${ }^{172}$ is bestowed with the powers conferred on a commissioner under the Public Inquiries $A c t,{ }^{17}$ including the power to require witnesses to produce any documents relevant to the matter of inquiry, ${ }^{174}$ such powers are rarely exercised and proceedings tend generally to be informal, with little or no advance disclosure and without any transcript kept other than the notes of the panel members.

The relative informality of SRB proceedings may appear to be appropriate having regard to the fact that appeals from an SRB decision are in the form of a new hearing. ${ }^{175}$ However, it remains that, notwithstanding the summary nature of SRB proceedings, deference is still accorded to SRB decisions on appeal. Furthermore, the Alberta Court of Appeal has

Alta. Reg. 190/2001.

Surface Rights Act, supra note 2, s. 8(3)(e).

R.S.A. 2000 , c. P-39.

Ibid, s. 4.

See supra note 135. 
criticized the practice of deferring the presentation of evidence until an appeal to the court is pursued. ${ }^{176}$

\section{B. Pipeline arbitration Committee Practice}

The conduct of pipeline arbitration committee proceedings, by contrast, is governed by relatively comprehensive rules of procedure promulgated under the $N E B A c t$, and is generally more formal. ${ }^{17}$ The rules of procedure dictate the content of notices of arbitration and the replies thereto, including the grounds, the relevant facts, the decision sought and a complete description and evaluation of the damages claimed. ${ }^{178}$ They also make ample provision for ensuring the advance disclosure, if requested, of the case each party is required to meet through the production and mutual exchange of supporting documents and exhibits proposed to be submitted at the hearing. ${ }^{179}$

The rules of the pipeline arbitration committee explicitly contemplate a pre-hearing conference for the purposes of formulating the issues in dispute and establishing procedural and disclosure requirements. ${ }^{180}$ Given that an appeal from the decision of a pipeline arbitration committee lies to the Federal Court only on questions of law or jurisdiction, ${ }^{181}$ advantage should be taken of the various procedural mechanisms provided under the $N E B$ $\mathrm{Act}$ and the pipeline arbitration committee's rules to ensure a fair hearing.

It is important to recognize that, as opposed to the SRB, pipeline arbitration committees are appointed on an as-needed basis. Individual members of the ad hoc committees may have limited or no surface rights or expropriation law background. Accordingly, counsel should not take for granted that a pipeline arbitration committee will be very familiar with the nuances of its legislation and rules of procedure, or the principles to be applied in the determination of compensation. (Alia. C.A.):

[T] he appellate judge should be clearly mindful that an appellant atcepts the burden of proving that the board's award was demonstrably wrong and that the award itself earns substantial evidentiary weight. Evidence which is not presented at the first opportunity and from a convenient source should be approached with caution. The ends of the Surface Rights Act are not promoled by inverting the board's assessment into a mere stalking horse or provisional inquiry which lends itself to easy adjustment under the guise of the statutory appeal. In contrast to the SRB's hearings, evidence is taken under oath and a transcript of the proceedings is kept.

17\% Procedure Rules, supra note 21 , ss. 4, 5, 7, 8.

17y Ibid., ss. 19-22. Section 19 provides a means for a pipeline arbitration committec to direct document production and to sanction a party that does not comply with a request for disclosure. With respect to the production and inspection of documents, note also s. 93(3) of the NEB ACI, supra note 4, which accords a pipeline arbitration committee the same powers as a superior coun of record. 


\section{Putting Best Case Forward}

Because claims for surface rights compensation must have a statutory basis, the legal counsel in surface rights cases have a particular responsibility for assembling and coordinating the evidence to be placed before the tribunal. ${ }^{182}$ Counsel should also understand that, whether dealing with the SRB from which there is an appeal in the form of a new hearing or a pipeline arbitration committee from which an appeal lies solely on questions of law or jurisdiction, there is no benefit in deferring the presentation of evidence. Furthermore, counsel should reasonably insist, notwithstanding the intended summary nature of surface rights proceedings, on the adherence to principles of natural justice and procedural fairness, and make appropriate use of the procedural mechanisms provided for production of documents and disclosure.

Consideration should also be given, whether in the context of advancing or opposing a claim, to ensuring that support for the compensation principles to be argued is established in the evidentiary record, such as the influence of extraneous factors in alleged sales comparables. Claims for compensation expressed in terms of annual or periodic payments should be reduced, at appropriate discount rates, to their present value to allow for an objective assessment of that compensation relative to actual land values. The nature of the heads of damages that are included in a claim for compensation for the acquisition of lands should also be scrutinized. Construction or disturbance damages, if not settled, and injurious affection should obviously be assessed separately based on evidence of quantifiable losses. Claims that include amounts for speculative future impacts, for which separate proceedings can typically be initiated if and when they occur, should also be identified.

\section{Conclusion}

Recent developments in surface rights law have brought considerable clarity to the issue of annual payments for pipeline rights-of-way in connection with both provincially and federally regulated pipelines in Alberta. Zubick practically closes the door to annual payments for provincially regulated pipeline rights-of-way. The recently released pipeline arbitration awards, though still subject to appeal on questions of law and jurisdiction, establish that the compensation determined under the $N E B A C t$, whether expressed as a lump sum or elected to be received by annual or periodic payments, should have the same present value. Unfortunately, the decisions in either context have done little to bring pipeline surface rights compensation in line with the more fundamentally sound principles of expropriation law.

Indeed, Zubick, through the introduction of a de facto corridor concept, has added an entirely new element of unpredictability and arbitrariness to pipeline surface rights compensation, specifically as it relates to injurious affection. This is compounded by the decision in Balisky that opens federally regulated pipeline operators to claims for compensation in connection with the controlled area established to either side of pipeline rights-of-way by legislation in the interest of public and environmental safety. 